\title{
Combined Dielectrophoresis and Impedance Systems for Bacteria Analysis in Microfluidic On-Chip Platforms
}

\author{
Cristina Páez-Avilés ${ }^{1, *}$, Esteve Juanola-Feliu ${ }^{1}$, Jaime Punter-Villagrasa ${ }^{1}$, \\ Beatriz del Moral Zamora ${ }^{1}$, Antoni Homs-Corbera 1,2,3 , Jordi Colomer-Farrarons ${ }^{1}$, \\ Pere Lluís Miribel-Català ${ }^{1}$ and Josep Samitier ${ }^{1,2,3}$ \\ 1 Department of Electronics, Bioelectronics and Nanobioengineering Research Group (SIC-BIO), \\ University of Barcelona, Martí i Franquès 1, 08028 Barcelona, Spain; ejuanola@el.ub.edu (E.J.-F.); \\ jpunter@el.ub.edu (J.P.-V.); bdelmoral@el.ub.edu (B.d.M.Z.); antoni.homs@icn2.cat (A.H.-C.); \\ jcolomer@el.ub.edu (J.C.-F.); pmiribel@el.ub.edu (P.L.M.-C.); jsamitier@ibecbarcelona.eu (J.S.) \\ 2 IBEC-Institute of Bioengineering of Catalonia, Nanobioengineering Research Group, Baldiri Reixac 10-12, \\ 08028 Barcelona, Spain \\ 3 CIBER-BBN-Biomedical Research Networking Centre for Bioengineering, Biomaterials and Nanomedicine, \\ María de Luna 11, Edificio CEEI, 50018 Zaragoza, Spain \\ * Correspondence: cpaezaviles@el.ub.edu; Tel.: +34-93-402-0876
}

Academic Editors: Amine Miled and Jesse Greener

Received: 23 February 2016; Accepted: 9 September 2016; Published: 16 September 2016

\begin{abstract}
Bacteria concentration and detection is time-consuming in regular microbiology procedures aimed to facilitate the detection and analysis of these cells at very low concentrations. Traditional methods are effective but often require several days to complete. This scenario results in low bioanalytical and diagnostic methodologies with associated increased costs and complexity. In recent years, the exploitation of the intrinsic electrical properties of cells has emerged as an appealing alternative approach for concentrating and detecting bacteria. The combination of dielectrophoresis (DEP) and impedance analysis (IA) in microfluidic on-chip platforms could be key to develop rapid, accurate, portable, simple-to-use and cost-effective microfluidic devices with a promising impact in medicine, public health, agricultural, food control and environmental areas. The present document reviews recent DEP and IA combined approaches and the latest relevant improvements focusing on bacteria concentration and detection, including selectivity, sensitivity, detection time, and conductivity variation enhancements. Furthermore, this review analyses future trends and challenges which need to be addressed in order to successfully commercialize these platforms resulting in an adequate social return of public-funded investments.
\end{abstract}

Keywords: dielectrophoresis; impedance; bacteria; on-chip; microfluidics

\section{Introduction}

Bacteria-related diseases caused by ingestion of contaminated food or water result in considerable morbidity and mortality representing a significant public health threat in developed and developing countries [1,2]. In the United States 3000 fatalities caused by food-borne infections were reported in 2012, and in 2013, 11,000 infections were recorded for the same cause [3]. Each year, there are more than 2.5 million deaths due to water-associated diseases worldwide [2,4]. In this context, diagnostic devices are extremely important for implementing an effective response to the prevention of bacteria related diseases [5,6], water treatment [7], and public health [8], preventing millions of deaths caused by the lack of these facilities [9].

Numerous methods exist to mitigate these issues based on the separation and concentration of bacteria (see Appendix A) [10]. Traditionally, this is performed in the laboratory and using commercial equipment [11]. Conventional pathogen detection methods include metabolic tests based 
on media, the use of enzyme-linked immunosorbents or pathogen-specific antibodies coated into magnetic beads, and oligonucleotide arrays for amplifying hybridized DNA fragments of bacteria. Some of the approaches to concentrate bacteria take advantage of the different properties of the cells. For example, physical properties are being exploited by techniques such as centrifugation or filtration [6]. Mass spectrometry (MS) and capillary electrophoresis (CE) take advantage of chemical or electrodynamic properties $[12,13]$. Other methods for separate and concentrate bacteria are based on immunological approaches such as immune separation [6] and the enzyme-linked immunosorbent assay (ELISA) [14]. Microscopy advances such as fluorescence or Raman microprobe spectroscopy (RMS) $[15,16]$ are also used. Others are nucleic acid probe-based such as the ligase chain reaction (LCR) [17], microarrays and Polymerase Chain Reaction (PCR) [18,19].

These diagnostic tools are elaborate and expensive because of the equipment and time (typically demanding several days) [20]. In particular, current methods require more than 5-7 days for identification of pathogenic bacteria [14]. In addition, the majority of them are not portable, prevention of contamination is difficult due to the small volumes, becoming a challenge to concentrate the bacteria in a microlitre or even nanolitre sample, and, in most cases, alternative methods require operation with a reagent, so the posterior bacteria detection process is rather complicated [21]. As an aggravating factor, the heterogeneity of individual cells makes these methods unsuitable for all kinds of bacteria [11,20].

The criteria recommended by the World Health Organization says that infectious disease diagnostic platforms must be specific, sensitive, simple-to-use, accurate, rapid, low-cost and robust $[22,23]$. There have been important attempts to accomplish these requirements, especially for laboratories interested in creating novel microfabricated structures for other specific uses [24]. However, even though there have been many published studies during these last two decades [5], few outcomes of microfabrication technologies have been successfully introduced onto the market (such as lab-on-a-chip (LOC) devices) [22,25,26]. Examples include the Immunocard STAT (Meridian Diagnostics, Cincinnati, OH, USA), which is a portable system and fast test for detecting Escherichia coli (E. coli) $\mathrm{O} 157+\mathrm{H} 7$ in faeces $[18,27]$. This kit has a high sensitivity $(87 \%)$ and specificity $(97 \%)$, however it cannot detect non-O157 STEC serogroups [28].

Some other examples include the Mycobacterium Tuberculosis Direct Test (MTD) from Gen-Probe (San Diego, CA, USA), the Probe Tec ET (BD, Franklin Lakes, NJ, USA) and the COBAS AMPLICOR (Roche, Pleasanton, CA, USA) devices for mycobacterial detection [18].

Despite the portability and highly-sensitivity advantages of these artefacts, not all of them meet time and cost needs. This generates an urgent necessity for fast, accurate, cost effective and more accessible technologies [25]. Due to this scenario, new methods of fast monitoring and characterization have been explored based on electrical properties of cells or particles [29,30]. In this context, electric field-based separation approaches are attracting interest because of their fastness, potential for automation, simplicity, portability, miniaturization, massive parallelization and labour-saving characteristics $[10,11,31]$. Based on their distinct electrical properties, dielectrophoresis (DEP) is a versatile technique used for the rapid detection and separation of particles. Even this technique was initially discovered by Pohl and colleagues in the 1950s [32], it has developed an exponential booming in the last fifteen years $[33,34]$.

An effective strategy to enhance sensitivity in a reduced detection period is by combining DEP with impedance analysis (IA) [35]. DEP and IA coupling has emerged in recent years. This can be evidenced in the growing number of published articles and citations reflected in Web of Science (WOS). This emergent trend is also evident for bacteria detection and concentration (Figure 1) since several research groups reported the simultaneous measure of the concentrated bacteria in a single piece of equipment $[14,30,35-38]$. 
30

․ Bacteria $\quad$ Publications

22.5

15

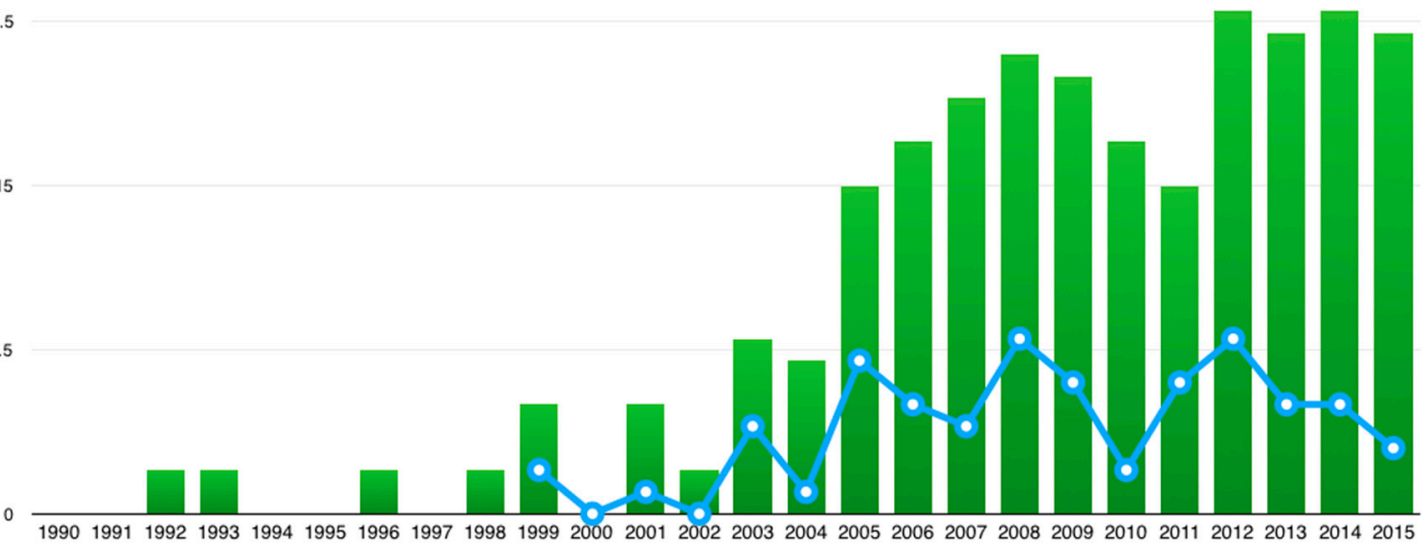

Figure 1. Publishing trends with "dielectrophoresis" and "impedance" keywords in Web of Science from 1990 to 2015. Blue line indicates the same keywords plus "bacteria".

The advantages of the combined method have prompted researchers to improve some technical aspects to overcome some of the challenges that are inherent from bacteria. In this context, numerous aspects related to manipulate, select and quantify bacteria have been improved over the years. Some of these aspects include both device and protocol optimization (Figure 2). We found that in publications where DEP and IA are combined for bacteria analysis, improvements related to selectivity, sensitivity, and detection times are the most studied challenges. Due to this scenario, and taking into account future challenges to take into consideration, authors find it important to analyse approaches from recent studies that share the same needs and goals when DEP and IA are being combined.

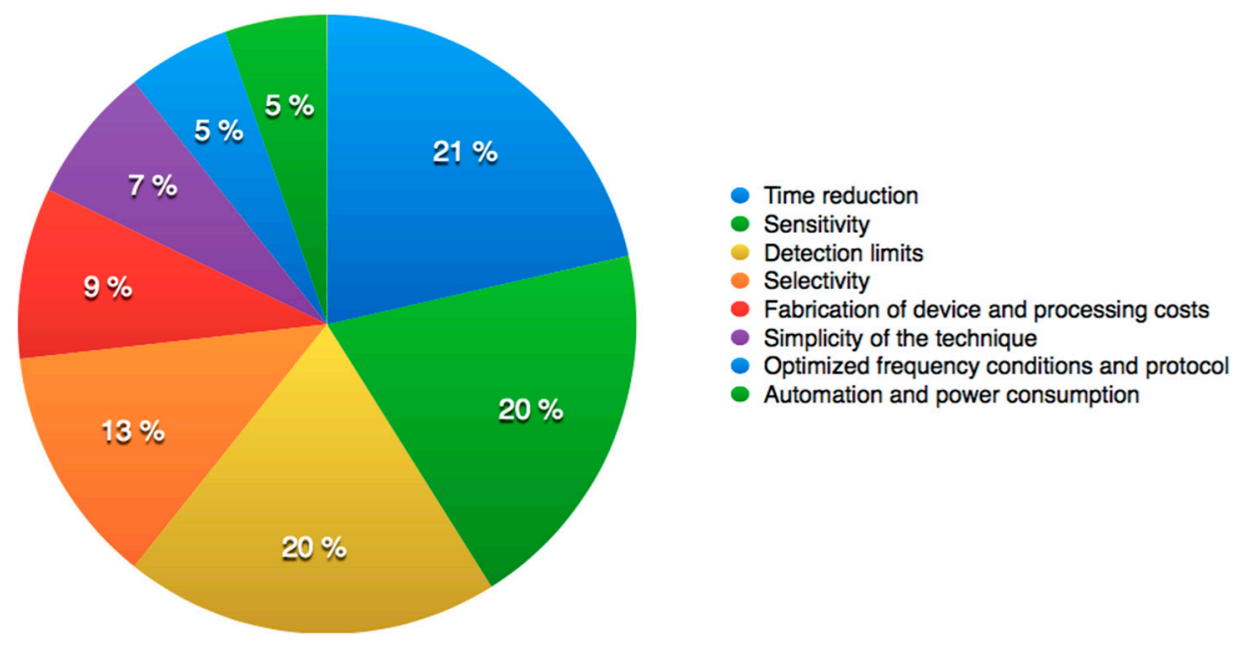

Figure 2. Addressed technical challenges that combined DEP and IA for bacteria analysis found in WOS publications from 1990 to 2015.

This document reviews the state-of-the-art approaches that take advantage of these two technologies focusing on bacteria concentration and detection, independently of their original growth medium. The aim is to analyse the challenges overcome and the principal opportunities that are facing LOC devices in a technology convergent scenario focusing on the emerging trend of microfabrication for envisaged LOC devices. It is necessary to review this combined approach, which can have a great impact in numerous fields such as medicine, biology, agriculture and environment $[18,39,40]$. 
The following Section 2 introduces the concept and applications of these two methods and reviews recent approaches using DEP and IA for bacteria concentration and detection. Next, in Section 3, some of the relevant operational improvements of recent studies are analysed. Section 4 describes future considerations and challenges to be taken into account for the commercialization of emerging DEP and IA micro-devices. Section 5 analyses the innovation and technology transfer aspects that these devices require for reducing the gap between research and society. Finally, in Section 6 we present the conclusions of this review.

\section{Theoretical Background}

\subsection{Dielectrophoresis (DEP)}

$\mathrm{DEP}$ is one of the currently used strategies in microfluidics for a versatile and label-free detection and separation of particles based on their distinct electrical properties [41]. It is described as the physical phenomenon whereby neutral particles move when a non-uniform electric field is applied according to the particles and medium physical properties $[39,42,43]$. The permittivity, conductivity, and dielectric properties determine the translational motion of the particle [44]. DEP uses a nontoxic electrical stimulation to induce a frequency-dependent dipole in cells [45]. The dielectrophoretic force is defined by Equation (1) [36,46,47]:

$$
\mathbf{F}=2 \pi \varepsilon_{m} R^{3} \operatorname{Re}\left[\underline{C M}(\omega) \nabla \underline{\mathbf{E}}^{2}(\mathbf{r}, \omega)\right]
$$

where $\mathbf{F}$ concerns to the dipole approximation to the DEP force, $\varepsilon_{m}$ refers to the permittivity of the medium surrounding the sphere, $\omega$ is the radian frequency of the applied field, $R$ corresponds to the radius of the particle, $\mathbf{r}$ is the spatial coordinate, and $\mathbf{E}$ refers to the complex applied electric field. $\underline{\mathrm{CM}}$ is the Clausius-Mossotti (CM) factor that is given by:

$$
\underline{C M}=\frac{\underline{\varepsilon}_{2}-\underline{\varepsilon}_{1}}{\underline{\varepsilon}_{2}+2 \underline{\varepsilon}_{1}}
$$

where $\underline{\varepsilon}_{1}$ and $\underline{\varepsilon}_{2}$ are the complex permittivities of the medium and the particle, respectively, and are each given by $\underline{\varepsilon}=\varepsilon+\sigma /(j \omega)$, where $\sigma$ is the conductivity of the medium or particle, $\varepsilon$ is the permittivity of the medium or particle, , and $j$ is $\sqrt{-1}$. The sign $(+/-)$ of the CM factor determines a positive DEP (pDEP) if the DEP force propels particles toward the electric-field maxima, or a negative DEP (nDEP) if the force propels particles toward the electric-field minima.

The wide range of capabilities enabled through the DEP technique include concentrating [21], sorting [48], rotating [49] and moving particles or biological material [50,51]. Studies have demonstrated that DEP is a promising technique for bacterial concentration with potential biosensor applications $[40,52,53]$ since it allows the advanced multifunctional and rapid detection of micro-organisms at lower flow rates and bacteria losses $[54,55]$. These capabilities are not only exclusive for bacteria but also for DNA [56], proteins higher than $105 \mathrm{Da}$ [42], cancer cells [57], foetal nucleated red blood cells, thrombloplasts [58], red/white blood cells [59], yeasts [60-62], viruses [63-65] and particles such as carbon nanotubes [66] and submicron particles [67].

Although DEP offers several advantages over other methods it has some limitations. Bacteria, as well as other single cell organisms, respond to their surroundings and media. Particle effects can be sensitive to the parameters of the medium such as $\mathrm{pH}$, conductivity, temperature and electrolyte valency. Additionally, the particle surface can absorb reagents present in the medium [68]. Therefore, these external factors must be controlled and consistent harvest concentrations and methods should be used from cultured cells in order to have consistent DEP results [69]. Moreover, it is important to previously modify the surface charge before changes in DEP behaviour. Another difficulty is the integration of DEP into miniaturized systems. This challenge is primarily due to complex electronic control architectures, and the incompatibility with heterogeneous sample matrices [70]. 


\subsection{Impedance (IA)}

IA is an electrochemical technique that provides information on bio-affinity-event induced changes in resistance and capacitance at the surface of a substrate or electrode [71]. Impedance analysis (IA) is related to electrical properties of particles. The impedance from each partial circuit and the total impedance were defined by [72] in the following equations:

$$
\begin{gathered}
\frac{1}{|Z|}=\frac{1}{\left|Z_{1}\right|}+\frac{1}{\left|Z_{2}\right|} \\
\left|Z_{1}\right|=\sqrt{R_{\text {sol }}^{2}+\frac{1}{\left(\pi f C_{d t}\right)^{2}}} \\
\left|Z_{2}\right|=\frac{1}{2 \pi f C_{d e}}
\end{gathered}
$$

where $f$ represents the excitation frequency, $R_{\text {sol }}$ the solution resistance, $C_{d t}$ the double layer capacitance, $Z_{1}$ the impedance of the $R_{s o l}$ and $C_{d t}, C_{d e}$ the solution dielectric capacitance and $Z_{2}$ is the impedance of $C_{d e}$. $Z$ is the total impedance of the parallel $Z_{1}$ and $Z_{2}$, as shown in Equations (4) and (5) [72].

Impedance frequency dependence, has been demonstrated to be efficient for characterizing cells and their comportment both in nano-, micro- and macro-fluidic systems $[73,74]$, therefore, this label-free technique is applied in many biological fields for biochemical concentration measurements $[71,75,76]$. Even though impedance detection is simple to design, and has high sensitivity and detection limits [77] the accurate measurement of biophysical properties of cells in microfluidic devices is limited by the high impedance of probe electrodes, the electric double layer and stray capacitance [78].

Impedance measurements are largely used in LOC devices to detect antibodies, virus, receptors, enzymes, DNA or many cell types (macrophages, endothelial cells, blood cells, fibroblasts, etc.) $[35,74,78-85]$. Single cell IA also resulted in an effective method for cell counting, discrimination, behaviour analysis and growth of bacteria [35,86,87]. Impedance microbiology measures the variations in electrical impedance of a culture medium or a reactive solution that results from the bacterial growth [55,88]. Previous studies have reported the use of this technique to detect and quantify different species of bacteria [14,89,90] such as Salmonella [91-93], E. coli [94,95], Listeria innocua and Listeria monocytogenes [96], Staphylococcus aureus [97], Enterococcus faeccalis [98], coliforms, Listeria spp., and L. monocytogenes [55]. Detection times ranging from 24 hours [99] to seconds [100] have been reported.

\subsection{The Combined Approach for Bacteria Concentration and Detection}

Currently, some biosensors are capable of combining DEP and IA on a microfluidic chip. These chips are devices usually comprised of a LOC and a customized electronic unit (Figure 3a). The DEP force pre-concentrates the sample in this electronic unit (Figure $3 b$ ) and IA monitors this concentrated sample (Figure 3c). DEP modifies the low-frequency capacitance $(<100 \mathrm{kHz}) \mathrm{due}$ to particle concentration on the electrodes, as the cells are trapped by the DEP force at the interdigitated array microelectrodes (IDAM), its permittivity substitute an equivalent volume of the medium. In consequence, the impedance among the electrodes will change with the variations in the complex permittivity of the medium that divides them and this can be plotted in a graph [44]. At high frequency ranges, the electrical signal applied to measure the impedance flows through the inner cell, reporting information about the inner cell properties, and it is better used for single-cell cytometry.

The combination of DEP and IA has demonstrated to be effective for the detection of DNA [101,102], RNA [100], yeasts [59,103], virus [104], cell trapping, detection and lysis [105,106], cancerous cells [107-110], and for bacteria [35,36,38,76,90,111-118]. Some of the devices used in bacteria concentration and detection are summarized in Table 1. 
Table 1. Combined dielectrophoresis and dmpedance systems for bacteria concentration and detection.

\begin{tabular}{|c|c|c|c|c|c|c|c|c|c|c|}
\hline Principle & Buffer & Conductivity & $\begin{array}{l}\text { Bio-Affinity } \\
\text { Element }\end{array}$ & $\begin{array}{c}\text { Applied } \\
\text { Frequency }\end{array}$ & $\begin{array}{l}\text { Flow Rate } \\
\text { Conditions }\end{array}$ & Bacteria & Sample Rate & Concentration & $\begin{array}{c}\text { Signal } \\
\text { Variation }\end{array}$ & Reference \\
\hline $\mathrm{DEP}+\mathrm{IA}$ & $\begin{array}{l}\text { Manitol } \\
\text { solution }\end{array}$ & $0.2 \mathrm{mS} / \mathrm{m}$ & $\begin{array}{l}\text { polyclonal } \\
\text { antibodies }\end{array}$ & $1 \mathrm{MHz}$ & $9 \times 10^{2} \mu \mathrm{L} / \mathrm{min}$ & $\begin{array}{c}\text { E. coli } \\
\text { strain K12 }\end{array}$ & NA & $10^{7}$ cells $/ \mathrm{mL}$ & NA & [38] \\
\hline EPA-DEP + IA & DI water & $0.2 \mathrm{mS} / \mathrm{m}$ & no element & $100 \mathrm{kHz}$ & $5 \times 10^{2} \mu \mathrm{L} / \mathrm{min}$ & $\begin{array}{c}\text { E. coli } \\
\text { strain K12 }\end{array}$ & NA & $10^{4}$ to $10^{2} \mathrm{CFU} / \mathrm{mL}$ & NA & [116] \\
\hline iDEP + IA & DI water & $1-2 \mu \mathrm{S} / \mathrm{cm}$ & $\begin{array}{c}\text { fluorescent } \\
\text { beads }(2 \mu \mathrm{m})\end{array}$ & $100 \mathrm{~Hz}$ & $40 \mu \mathrm{L} / \mathrm{min}$ & $\begin{array}{l}\text { B. subtilis } \\
\text { spores }\end{array}$ & $10 \mu \mathrm{L} / \mathrm{min}$ & $10^{6}$ spores $/ \mathrm{Ml}$ & NA & [46] \\
\hline nDEPpDEP + IA & $\begin{array}{l}\text { Manitol } \\
\text { solution }\end{array}$ & $0.1 \mathrm{mS} / \mathrm{m}$ & no element & $\begin{array}{l}1 \mathrm{kHz}(\mathrm{nDEP}) \\
\text { and } 100 \mathrm{kHz} \\
(\mathrm{pDEP})\end{array}$ & $0.27 \mathrm{~m} / \mathrm{s}$ & $\begin{array}{c}\text { E.c coli } \\
\text { strain K-12 } \\
\text { (NBRC3301) }\end{array}$ & NA & NA & NA & [35] \\
\hline $\mathrm{pDEP}+\mathrm{IA}$ & $\begin{array}{l}\text { PBS solution } \\
\text { and DI water }\end{array}$ & low & $\begin{array}{l}\text { polyclonal } \\
\text { antibodies }\end{array}$ & $100 \mathrm{~Hz}-1 \mathrm{MHz}$ & $2-4 \mu \mathrm{L} / \mathrm{min}$ & $\begin{array}{l}\text { E. coli } \\
\text { O157:H7 }\end{array}$ & $3 \times 10^{5} \mathrm{CFU} / \mathrm{mL}$ & $3 \times 10^{2} \mathrm{CFU} / \mathrm{mL}$ & NA & [14] \\
\hline $\mathrm{DEP}+\mathrm{IA}$ & Milli-Q water & $\begin{array}{c}0.5 \times 10^{-3} \text { to } \\
2.5 \times 10^{-3} \mathrm{~S} / \mathrm{m}\end{array}$ & no element & $500 \mathrm{~Hz}$ to $5 \mathrm{kHz}$ & $10 \mu \mathrm{L} / \mathrm{min}$ & $\begin{array}{c}\text { E. coli } \\
5 \mathrm{~K} \text { strains }\end{array}$ & NA & $2 \times 10^{7}$ cells $/ \mathrm{mL}$ & $3.1 \%$ & {$[36]$} \\
\hline DEP + IA + (AC-EO) & $\begin{array}{l}\text { Phosphate } \\
\text { buffered saline } \\
\text { (PBS at pH 7.4) }\end{array}$ & $1.8 \mathrm{mS} / \mathrm{m}$ & no element & $\begin{array}{c}10 \mathrm{kHz}-63 \mathrm{MHz} \\
\text { (AC-EO) }\end{array}$ & $5 \mu \mathrm{L} / \mathrm{min}$ & $\begin{array}{l}\text { S. epidermidis } \\
\text { ATCC } 35984\end{array}$ & NA & $\begin{array}{c}3.5 \times 10^{5} \mathrm{CFU} / \mathrm{mL} \text { and } \\
3.8 \times 10^{6} \mathrm{CFU} / \mathrm{mL}\end{array}$ & NA & [37] \\
\hline $\mathrm{nDEP}+\mathrm{IA}$ & $\begin{array}{l}\text { Drinking } \\
\text { water }\end{array}$ & $\begin{array}{c}0.0086 \mathrm{~S} / \mathrm{m} \\
\text { (aprox) }\end{array}$ & no element & 1 kHz-10 MHz & $25 \mu \mathrm{L} / \mathrm{min}$ & $\begin{array}{c}\text { E. coli } \\
\text { ATTC } 8739\end{array}$ & $(150-1500 \mathrm{CFU} / \mathrm{mL})$ & $300 \mathrm{CFU} / \mathrm{mL}$ & $1.13 \% \pm 0.37 \%$ & [30] \\
\hline
\end{tabular}

DEP: dielectrophoresis; iDEP: insolator-based dielectrophoresis; pDEP: positive dielectrophoresis; nDEP: negative dielectrophoresis; IA: impedance analysis; EPA: electropermeabilization; 


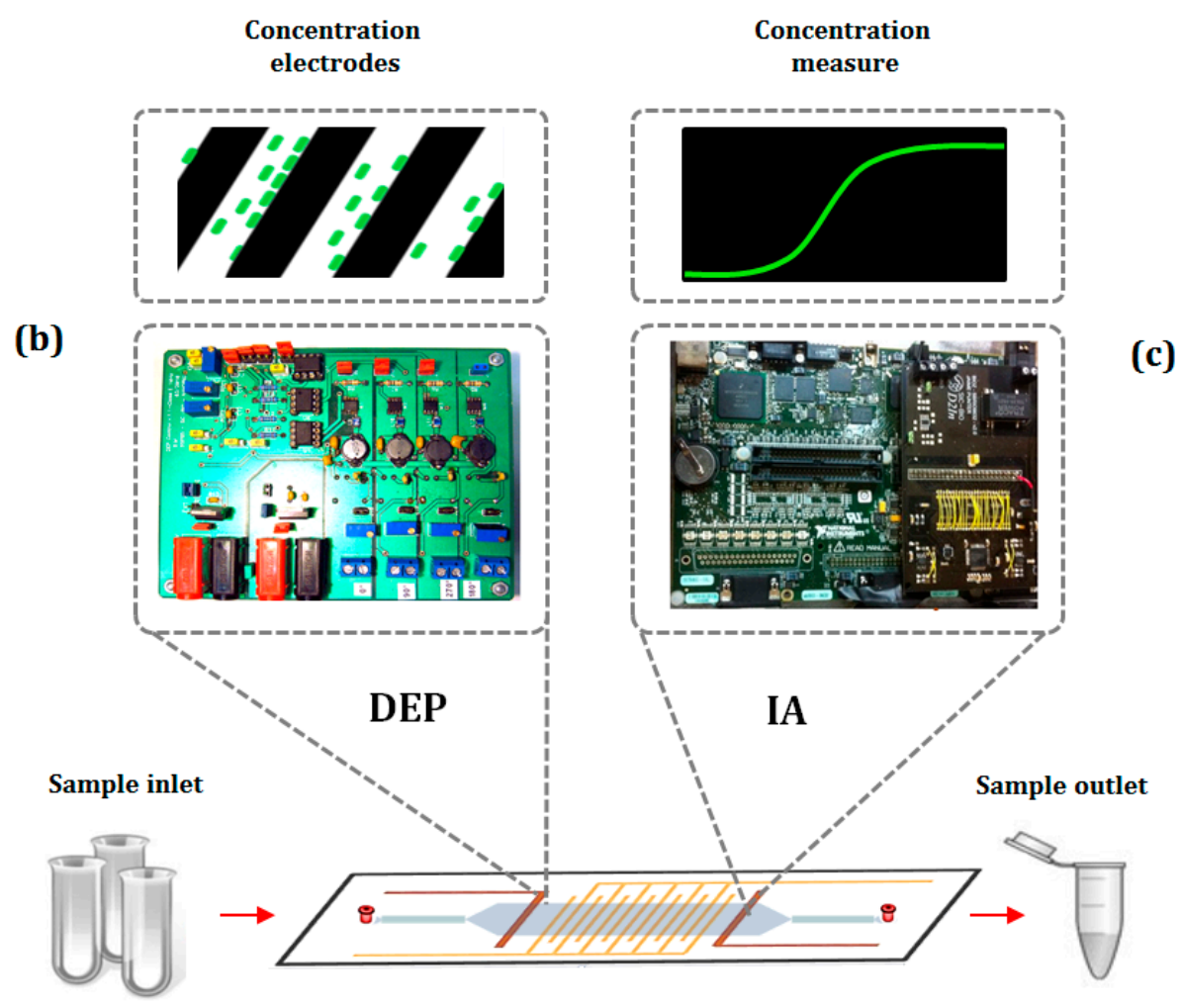

(a)

Figure 3. Scheme of the overall process. (a) The electronic module; (b) Bacteria concentration by dielectrophoresis; (c) Concentration measure by impedance analysis (adapted from [36]).

\subsection{Recent Approaches}

One of the first approaches combining DEP and IA, was developed by [119]. This group of researchers studied the quantitative estimation of E. coli in an aqueous medium by applying positive DEP (pDEP), which occurs when the cell is attracted to the electrical field maximum. The time required for detection was $10 \mathrm{~min}$. In the same year, viable and non-viable E. coli were selectively detected by [38] by studying the effects of viability and sterilization on DEP and impedance measurements. Bacteria trapping was tested by using different frequencies $(100 \mathrm{kHz}$ and $1 \mathrm{MHz})$. By applying $1 \mathrm{MHz}$ of electrical field, they selectively collected viable and heat-sterilized non-viable bacteria by pDEP and sensed them by DEP and IA. They argued that heat treatment is the responsible of the change of the dielectric properties of cells, showing a decrease in the cytoplasmic conductivity.

Two years later, higher sensitivity for bacteria detection was achieved by incorporating electropermeabilization (EP). EP is the implementation of a strong electric field in order to increase membrane permeability. If the membrane is permeable, intracellular ions are liberated and disseminated into the external medium acting as ionic current carriers. This increases the conductance and avoids electrolytic contamination produced by metal ions. They finally obtained a concentration of bacteria of $10^{4}-10^{2} \mathrm{CFU} / \mathrm{mL}$ after $3 \mathrm{~h}$ of experimentation [116].

Another study focused on the enrichment of bacteria was developed by [46]. This was the first study reporting the implementation of insulator-based dielectroforesis (iDEP) and IA for B. subtilis concentration and detection. iDEP is a technique adapted from DEP which provides an insulating layer on the top of the electrodes to protect them, and where the substrate material is the only material which is in contact with the sample $[37,120,121]$. The possibility of linking iDEP with impedance detection resulted in trustworthy enrichment of particles. With this approach they also demonstrated that impedance detection is dependent on the signal frequency and particle concentration (Figure 4a). 
(a)

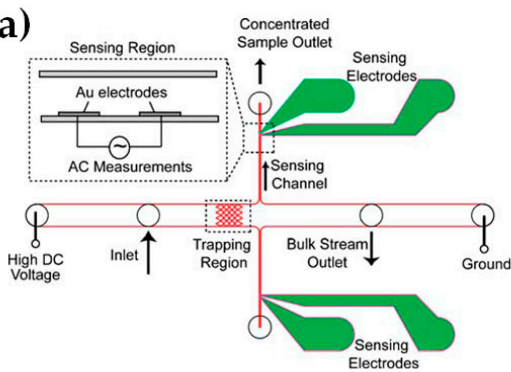

(c)

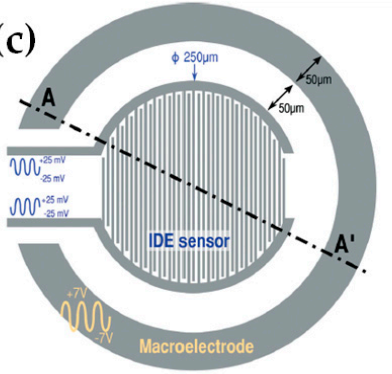

(b)

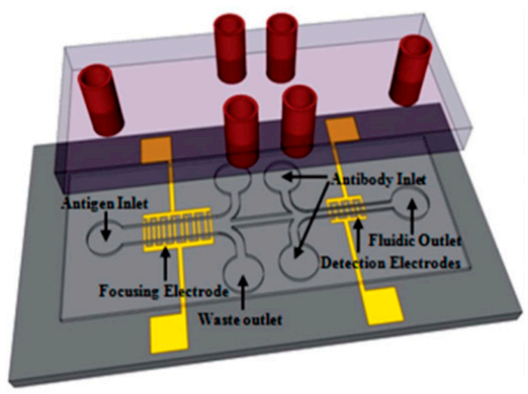

(d)

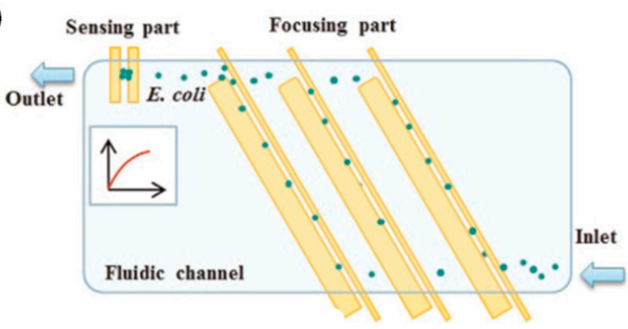

Figure 4. Schematic of bacteria concentration and detection approaches using DEP and AI. (a) This device selectively concentrates pathogens on the base of their size by DEP and high DC voltage. The concentrated sample is released for the measure of AC impedance by a pressure-driven flow [46]; (b) Design of a DEP and IA device with two IDAMs in a SU-8 microchannel [14]; (c) A device containing a IDAM (for capacitive sensing) and a macroelectrode (for electrokinetics). A cross.section of the $\mathrm{AA}^{\prime}$ plane [37]; (d) Design of the sensor consisting of a pDEP region and a sensing region that employs dielectrophoretic impedance measurements [30].

Alternatively, [35] doubled the sensitivity of E. coli detection by implementing negative DEP (nDEP) before applying pDEP and impedance for detection. In nDEP, particles are attracted to an electrical field minimum. They used a device composed of two microelectrodes. The first microelectrode was used for bacteria concentration using $\mathrm{nDEP}$ energized with $1 \mathrm{kHz}$ frequency. The second was used for bacteria detection by pDEP energized with $100 \mathrm{kHz}$. The different voltage values were determined through a theoretical prediction in order to know at what frequencies nDEP or pDEP occurs. Their approach is useful to reduce the longer detection periods often required for low bacterial concentration samples where it is necessary to trap a large number of cells.

In 2013, Dastider and collaborators developed an impedance biosensor for detecting of E. coli O157:H7 that also improved measurement sensitivity by using pDEP and two sets of gold IDAM (Figure 4b). Initially, positive electrophoresis was used to focus and concentrate the bacteria in a microchannel in the first set of IDAMs and the second set was used for impedance measurements. Their lowest limit of

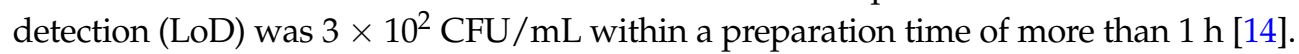

More recently, another approach aimed at increasing the sensitivity of the device is reported by [37]. They developed a device that combines a circular shaped IDAM, with a surrounding macroelectrode. These allowed a higher sensitivity surface sensing and volume in order to trap bacterial cells by incorporating AC-electro-osmosis (AC-EO) (Figure 4c). Their device demonstrated that the LoD can be reduced from $3.8 \times 10^{6} \mathrm{CFU} / \mathrm{mL}$ to $3.5 \times 10^{5} \mathrm{CFU} / \mathrm{mL}$ by applying this electrohydrodynamic effect in a whole-cell Staphylococci epidermidis after $20 \mathrm{~min}$ of incubation. This LoD reduction is due to the fluid flow generated by AC-EO that causes indirect bacterial motion, improving the sensitivity of detection. Again, these types of devices are necessary for low bacterial concentrations. However, based on their detection time, they are not adequate at emergent sanitary conditions.

In this context, different solutions and approaches have been reported, such as [30,31]. [30] developed a device capable of detecting bacteria in $1 \mathrm{~min}$. This was performed in drinking water for E. coli (Figure 4d). They used pDEP since drinking water's low conductivity makes it difficult to 
analyse by nDEP. In this study two electrode widths (100 and $30 \mu \mathrm{m})$ were configured for a bacteria flow rate of $1500 \mu \mathrm{L} / \mathrm{h}$. Also, they determined that the optimal detection limit is $300 \mathrm{CFU} / \mathrm{mL}$ across different populations examined (150, 300, 750, and $1500 \mathrm{CFU} / \mathrm{mL})$.

A more rapid and continuous flow microfluidic chip was developed by [36] capable of injecting, trapping, cleaning and continuously measuring impedance every $30 \mathrm{~s}$. The device was capable of concentrating $2 \times 10^{7}$ cells $/ \mathrm{mL}$ of E. coli $5 \mathrm{~K}$ strains at several continuous flows ( 5 to $30 \mu \mathrm{L} / \mathrm{min}$ ) with the utilization of pole structures, and $44.2 \%$ less bacteria losses.

All of these contributions showed that DEP and IA for bacteria concentration and detection is being enhanced in various ways, namely, LoD, sensitivity and detection times. This last point for example, has been reduced from hours to minutes. Additionally, they are not exclusive to one species of bacteria. In this regard, there has been much progress concerning selectivity, conductivity variations and flow conditions, involving advances in such different technologies as microfluidic design, microstructure engineering, electronic instrumentation, and computational data processing. These improvements are addressed in the following section.

\section{Operational Improvements of Combined DEP and IA Targeting Bacteria}

\subsection{Selectivity and Sensitivity}

Methods for detecting bacterial have the imperative necessity to be selective and sensitive due to the few number of bacteria present in a sample [77]. Even more, when pathogenic bacteria is often present with non-pathogenic ones [122]. However, the accurate measurement of biophysical properties of cells in microfluidic devices is limited by the high impedance of probe electrodes, the electric double layer and stray capacitance [78].

Some of the approaches to improve detection selectivity when combining DEP and IA take advantage of the agglutination phenomenon caused by the antigen-antibody bonding. This bonding allows immobilization of the bacteria on the device $[30,123]$ according to their viability or species type [122]. The immobilized antibodies and the target bacteria banded to the electrode change the electrochemical impedance, detecting the target bacteria and measuring the impedance of the antibody [35]. After voltage is applied and turned off, the sample solution is washed away, excluding the target bacteria. Bacterial cells can conduct when they are present in between two conductors in an IDAM array because it cell wall, cytoplasm and few other cell components act as conductors [124]. Then the bacteria could be identified and quantified by quantifying the electrode's residual impedance [35].

According to [38], there are two methods of using antigen-antibody reaction for bacteria selection. The first one consists in adding the antibody to the cell suspension for the agglutination of the antibody-specific bacteria after DEP enrichment. The second method consists in immobilizing the antibodies onto the microelectrode before DEP, in order to bound the immobilized antibody into the antibody-specific bacteria.

Undesired non-specific bacteria binding still occurs even using this antibody-modified chip [122] and the bio-recognition component can be a disadvantage [77]. Moreover, polyclonal antibodies used as the bio-affinity element to characterise the bacteria require consumption of reagents, increasing costs and detection times [24].

Improved methods for bacteria selectivity are not exclusive of vegetative forms but also to sporulated forms. Characterization of this structure is not easy because dormant cells are not actively generating considerable levels of metabolites. However, bacterial spores have great interest, for example, for Bacillus anthracis. [125] have demonstrated that spores selectivity could be achieved by combining DEP and IA. By testing over a mixture of B. mycoides and B. subtillis spores, they showed that the electrical response of a spore in a gap between two planar microelectrodes can discriminate between different species and subspecies of Baccillus. In presence of an electrical potential, the surface charges, responsible of the hydrophilicity of spores, serve as charge carriers. The character of this surface charge explains the species-specific variations in hydrophobicity and impedance too. 
Spore selectivity can be improved by using fluorescent polystyrene beads in order to eliminate particles of interest. [46] demonstrated this improvement in B. subtillis spores. They injected fluorescent polystyrene beads with $2 \mu \mathrm{m}$ of diameter into a microchannel (10 $\mu \mathrm{L} / \mathrm{min}$ of injection rate). The resulting scenario showed that only one particle type can be selectively concentrated and diverted down the side channel, allowing the approximation of the concentration of the particles by impedance measurements. Contaminants are putting apart or reduced facilitating the detection only of the particles of interest. The use of fluorescent polystyrene beads can be extent to nano-sized particle detection [126], however, prior labelling requirements can be a drawback of this technique [127].

\subsection{Fouling}

On the other hand, label-free approaches have demonstrated to improve other operational challenges such as fouling (the adhesion of cells to the electrode edge), electrode delamination or bubble formation. [30] used iDEP, also known as contactless DEP (cDEP), with IA using a passivation layer on the electrode to permit efficient bacteria focusing under high flow conditions. In this study, they also demonstrated that the geometry and disposition of electrodes play an important role in cDEP since a decreased electrode width increased the sensitivity of the sensor. They evaluated several types of electrodes tested under same experimental conditions for E. coli and showed that a gap among the electrode edge and the channel wall, as well as the passivation layer used were crucial for effective DEP focusing. This phenomenon could be seen at the Figure 5, which depicts the motion of E. coli in the focusing electrode. Due to the round shape of the electrode edge, the bacteria were liberated at the end of the electrode. Figure 5b shows the control experiments with no passivation layer and Figure $5 c$ using passivation layer without a gap between the channel wall and the electrode edge. In both, the high pDEP force caused the incapability of E. coli to flow along the electrode edge.
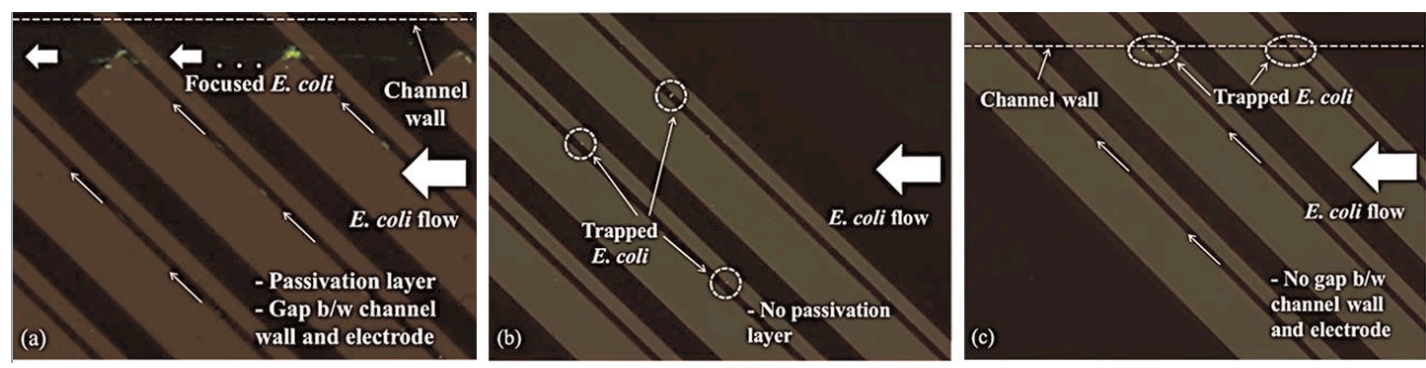

Figure 5. Characterization of pDEP-based E. coli focusing. (a) The electrode is covered by a passivation layer. Cells flow through the electrode edge and are liberated at the end of the electrode; (b) Cells are not flowing. They persist trapped on the electrode, which is not covered by a passivation layer; (c) Cells flow along the electrode but not liberated from it (reproduced with permission from [30]).

This technique has some drawbacks. First, the use of the passivation layer requires special attention in order to achieve successful focusing and sensing. For instance, a high electric field could reduce the layer lifetime [30]. Second, joule heating and an increasing of temperature is caused by the highly conductive biological fluid and the high electric field intensity [120]. Additionally, manipulating particles and cells is difficult with iDEP and cDEP due to the collecting patterns, confirming this is still challenging [128].

Rather than using patterned surface electrodes, an electrically conductive liquid metal used as the electrode can be controlled. This improvement refers to the concept of liquid electrodes initially developed by $[129,130]$. Electrodes constitute a very important element in these systems but their implementation has some disadvantages. First, they require complicated fabrication procedures [120,131]. Second, they are susceptible to suffer from fouling, bubbles, and low throughput [120]. Liquid electrodes are recessed electrodes positioned perpendicularly to the main channel. Electrodes are then polarized by inverted signals in order to generate the lateral DEP force 
necessary for manipulation of particles in the main channel [132]. The result is to a homogeneous electrical field over the total channel [130]. Even these electrodes improve the spatial resolution and increases the resolution range with a simplified fabrication process and reduced costs, it has been shown that decreases the sensitivity compared to top-bottom electrodes [133].

\subsection{Buffer Conductivity Variations}

On the other hand, another very critical problem in impedance measurement involving bacterial species is the buffer conductivity. Buffer is the liquid where cells are suspended, independently of its origin and/or composition, and this is considered as our media. There is a governing effect of sample conductivity variations on the impedance quantifications when this media is not controlled [77]. The cellular solution conductivity changes through time, and produces a masking effect on the impedance measurements. Therefore the quantified impedance is totally dependent to sample buffer conductivity, and not to the concentration of bacteria $[77,134]$.
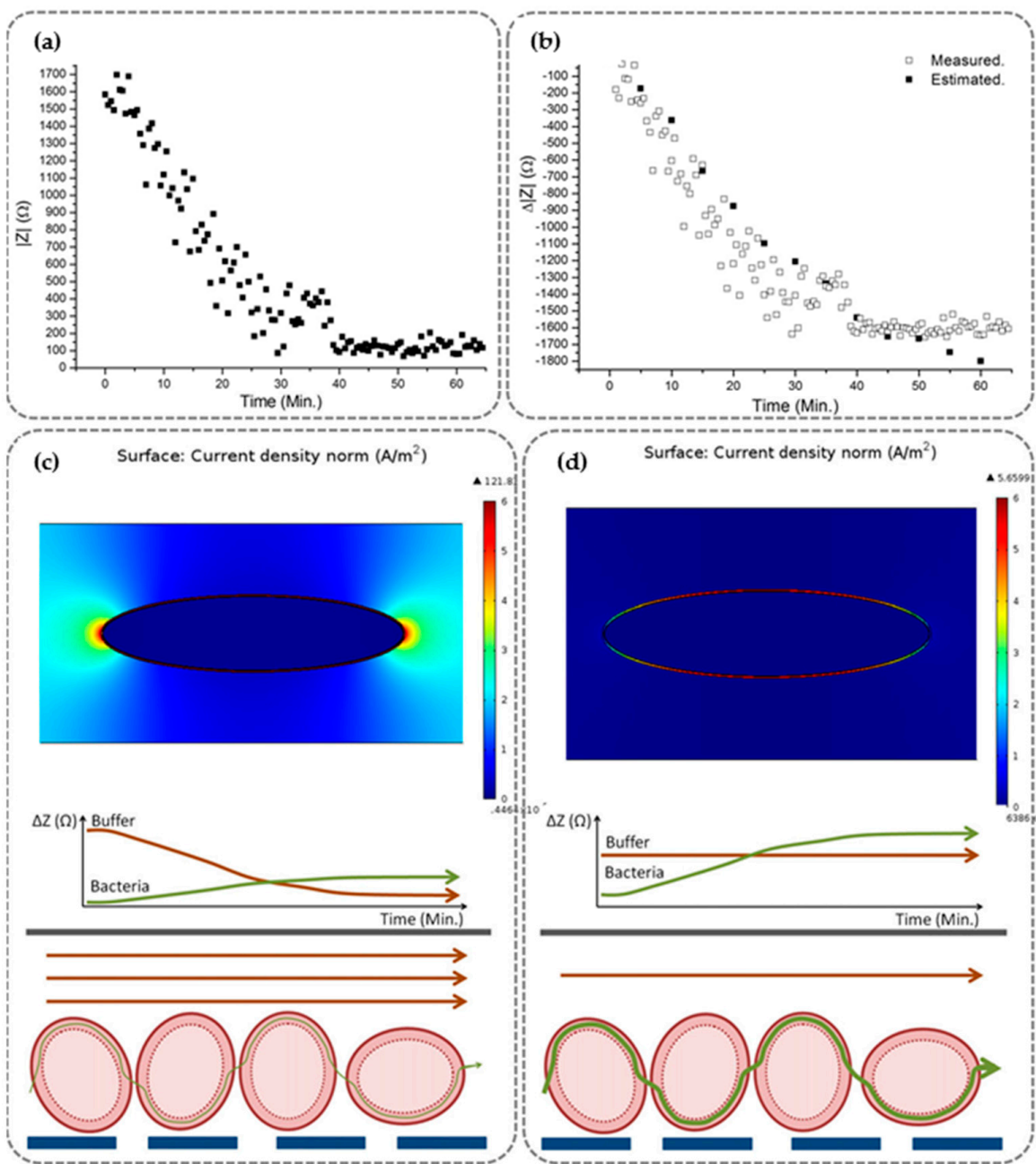

Figure 6. (a) Impedance magnitude; (b) Estimated versus experimental impedance; (c) Simulation of Comsol multiphysics of a single diluted cell on buffer of high conductivity steady buffer; (d) low-conductivity steady buffer. Flow path and influence to impedance quantification of both buffer conductivity and trapped bacteria (reproduced with permission from [36]).

Only one previous study has confronted conductivity variations. [36] developed a device in which the variation of the conductivity was corrected through a specially designed automated protocol, composed of media conductivity stabilisation and DEP voltage disconnection during impedance 
measuring. On this study, the conductivity of the media linearly increased from $8.2 \times 10^{-5} \mathrm{~S} / \mathrm{m}$ to $2.5 \times 10^{-3} \mathrm{~S} / \mathrm{m}$. The stabilisation was achieved by controlling buffer conductivity using Milli-Q water. Impedance changes are highly associated to variations in the conductivity of the media due to bacteria when cleaning processes does not control the cells' media. Therefore, for ensuring a reliable measurement, it was implemented an automatized and periodic cleaning process.

The measured bio-impedance $(|Z|)$, in Figure $6 a$, demonstrates that the impedance decreases and the concentration of trapped cells increases, without taking the frequency into account. Figure $6 \mathrm{~b}$ shows the change of impedance $(\Delta|Z|)$ during the trapping course.

This new optimized protocol enables an electrode multiplexing system that disables DEP voltage when the IA is enabled for concentration monitoring. Changes in sample conductivity dominate the bio-impedance measurements when left uncontrolled. With this approach, the surface current density of bacteria (Figure $6 \mathrm{c}, \mathrm{d}$ ) and the impedance is totally related to the conductivity from the sample buffer instead of the bacteria concentration (Figure 6c). Current density is principally placed at the cell membrane by controlling buffer conductivity (Figure 6d), and changes in impedance related to the quantity of trapped bacteria. Furthermore, including a bacteria-cleaning step in the protocol demonstrated an effective bio-impedance control of the resulted sample concentration in this study [36]. If applied, this last reviewed improvement could change the data of previous results. Moreover, all the improvements are a "must" to be considered in the development of new emerging devices.

\section{Future Perspectives of DEP and IA On-Chip Platforms}

Despite the numerous advances in DEP and IA systems for bacteria concentration and detection evidenced throughout this review, commercialization remains a daunting task to be addressed in the coming years. Currently, it is still challenging to find electronic devices combining electronics and microfluidics for a portable DEP system [41]. Regular commercial devices do not demonstrate a superior alternative required to replace current technologies [26]. Moreover, most of the microfluidic devices are limited to proof-of-concept and publications $[19,135]$ due to the absence of consumer development and validation of market needs [135].

Because of the size of bacteria (most of them are $0.2 \mu \mathrm{m}$ of diameter), miniaturization and automation of the complete system constitutes a challenge to be addressed [63,136-138]. Research for miniaturization is also driven by the need to reduce costs by, among other things, increasing throughput and automation [24]. Due to the current trend to develop fully-integrated lab-on-a-chip devices instead of bench-top devices [26], efforts need to be made to successfully integrate laboratory functions on single miniaturized chips as new emerging diagnostic devices [25]. Therefore the final product should be self-contained, not requiring prior sample treatment, preparation, or amplification [135,139].

Since microfluidic systems must contain some generic methods [19], many innovations are elaborated and difficult to fabricate. Therefore, the device requires labour intensive manufacturing techniques. The seamless integration of the different components will determine the portability, usability, simplicity of manufacturing and costs [135,139].

LOCs are considered the result of the convergence of chemical and biological analysis techniques and the engineering of computer chips [140,141]. This convergent scenario in areas such as micro-electronics, micro-sensors and bio-compatible materials makes possible the availability of cheaper and faster bio-devices [142]. It is in this context that there is a growing interest in fostering the cross-fertilization of Key Enabling Technologies (KETs), since these create value beyond the sum of the individual technologies for developing innovative and competitive products, goods and services [143-145].

Most of the microfluidic on-chip platforms for bacteria detection included in this work are the result of the convergence of KETs, namely, industrial biotechnology and micro- and nano-electronics. In particular, Nanotechnology is seen as one important KET for future diagnostics. An example is evidenced in the impact that nanospheres or nanoparticles can have in these devices $[100,146]$. In addition, it is expected that in the future, the convergence of other tangential KETs, such as 
Advanced Materials and Advanced Manufacturing Systems, could allow not only more effective and efficient analysis but also solve manufacturing and cost constraints. Therefore the key parameter to consider is industrialization, since production approaches always remain behind a new technology.

Even though there are pending challenges-opportunities, it is expected that point-of-care (POC) devices can generate $\$ 34.6$ billion by 2021 on the global diagnostic market $[147,148]$. On the other hand, the market for microfluidics has been estimated to be $\$ 1.6$ billion with a forecast rise to \$3.6-5.7 billon by 2018 [135]. It is expected that the rise of POC testing could improve the accessibility to medical services and improve and facilitate healthcare programs [149]. Undoubtedly, the application of major interest for microelectromechanical devices is balanced towards medicine [150]. It is expected that in the coming years, there could be widespread use of LOC and POCs in food safety and medical diagnostics [151,152].

\section{Technology Transfer and Social Return Challenges in Microelectronics}

New emerging technological innovations such as those discussed in this review for bacteria concentration and detection should be assessed not only from a research perspective, but also taking into account a market-orientation view in order to foster innovation and successfully reach the final process of technology transfer, which is commercialization. Academics tend to focus their research on the proof-of-concept phase for a single-chip experiment (chip-to-chip or batch-to-batch) [135,139], therefore there is a conflict of interest between academia and market which results in reproducibility failures and LOC variabilities [139].

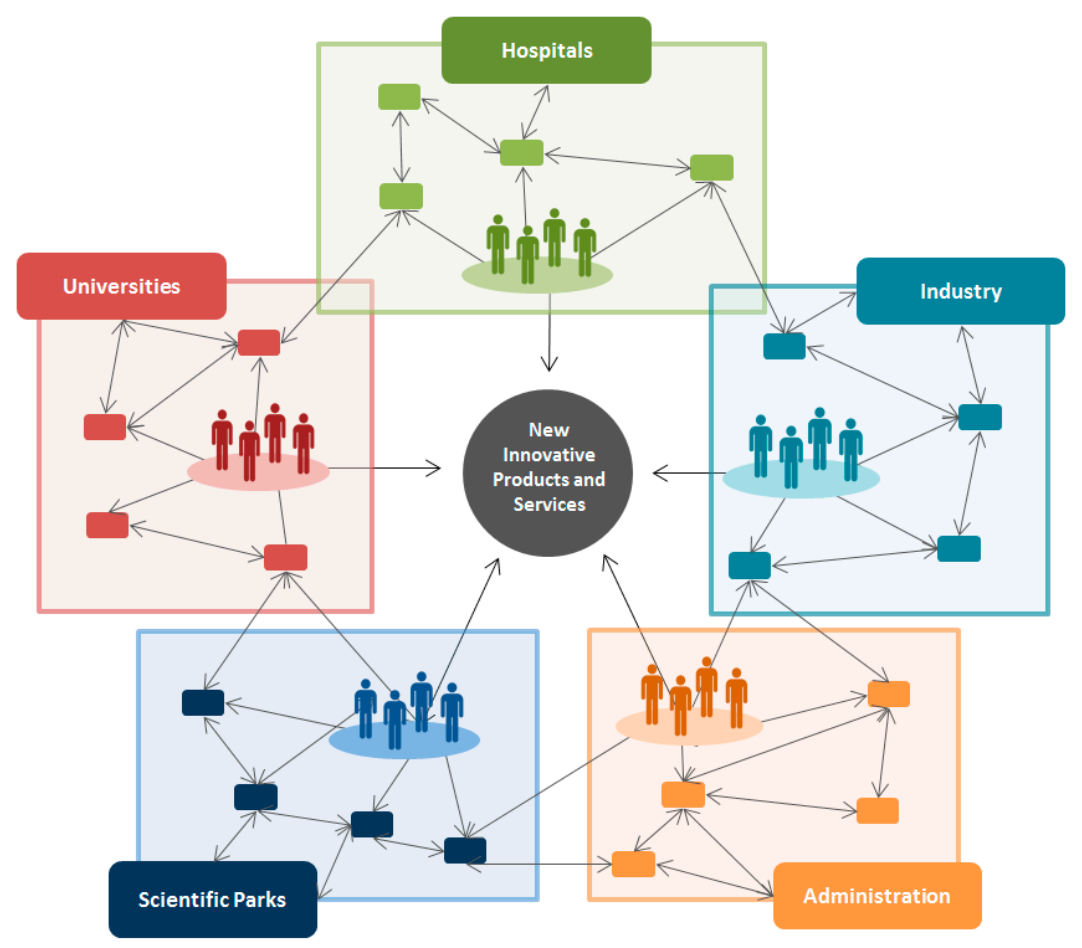

Figure 7. Scheme of a multidisciplinary ecosystem of stakeholders collaborating in the development of emergent devices (inspired from [144]).

This concern has been addressed by the European Commission in recent years through their Framework Programme Horizon 2020, the financial initiative for research and innovation. Unlike previous funding initiatives, this is advocated to solve major societal challenges by overcoming the gap between research and market through the industrialization of previously mentioned KETs.

Social availability and accessibility of these technologies is a little discussed topic. Bacteria diagnostic tests need to scope large populations; they will have more impact when everyone can use them $[153,154]$. 
In this sense, microfluidics should satisfy the needs of non-expert users so that it can become a routine operation for untrained personnel $[19,139]$. Moreover, market uncertainty is reduced if the product does not require new skill sets from consumers [155]. In particular, modelling and designing DEP and IA devices become critical for implementing systems for near-patient clinical analysis [41]. These devices would constitute an alternative of existing technologies, with minimal technological investment and allowing a higher level of market acceptance and uptake [139].

These technological innovations require the coordinated collaboration of researchers, through innovation communities, in order to overcome research-market barriers [156]. Since healthcare is a global process, knowledge-share activities require the continuous interaction of multiple actors [157]. Therefore, transferring knowledge from basic research to commercial organizations should be a responsibility from the universities, research centres, governmental bodies and the industrial sector [158], facilitating therefore shortest times-to-market [159].

In recent innovation models literature, there has emerged the "Five-Helix Model" concept [160,161] aimed at satisfying the needs of the healthcare system including life sciences such as medicine, biotechnology and the nanotechnologies. This concept emphasises the need of a coordinated cooperation among universities, hospitals, industry, administration and science parks (Figure 7). The schematic framework of this process resumes a multidisciplinary team, in the context of an innovative community ecosystem in which the resulting scenario can be the social return of public-funded investments.

\section{Concluding Comments}

In recent years, emerging microfluidic platforms combining dielectrophoretic and impedance analysis for bacteria concentration and detection have been developed for replacing conventional diagnosis techniques. These approaches respond to the need for more rapid, portable, simple and labour-saving bacteria-detection devices. Different research groups have demonstrated their feasibility by addressing different aspects. LoD and detection time, as well as sensitivity of devices have been modified during recent years. Some improved approaches include technical adaptations such as EP and AC-EO. In addition, several groups have developed enhancements in the combined system aimed at improving selectivity, detection times, conductivity variations and particle manipulation.

It has been shown that selectivity could be improved by the use of antigen-antibody or fluorescent polystyrene beads, this last approach used in sporulated stages of bacteria. However, the costly and time-consuming difficulties of these labelled-based methods have resulted in other selectivity improvements such as the cDEP or iDEP, aimed at avoiding fouling by the use of a passivation layer. The introduction of Impedance Analysis strengthen the characteristics of a DEP-based devices, being a rapid, sensitive and accurate technological tool for bacteria concentration measurement, as well as a straightforward technological application of feedback between the device and a post-processing tool. This feedback allows the system to perform critical functions aiming for a rapid, accurate and selective device, such as the real-time interaction with the user, the automation of the process, and the implementation of intelligent algorithms to enhance its performance. As an example, conductivity variation correction, as it has been demonstrated by only one group of researchers, can be executed through a specially designed automated protocol. These approaches are the basis of new microfluidic platforms with other future challenges still to be addressed, for example, their miniaturization, automatization and commercialization by considering economies of scale, customer acceptance, market adoption, and what is also important: accessibility and social benefit. All of these perspectives cannot be accomplished without a collaborative ecosystem of multidisciplinary stakeholders able to transfer technological innovations by narrowing the gap between basic research and society.

Acknowledgments: This work has been financially supported from the Commission for Universities and Research of the Department of Innovation, Universities, and Enterprise of the Generalitat de Catalunya (2014 SGR 1442).

Conflicts of Interest: The authors declare no conflict of interest. 


\section{Appendix}

Table A1. Conventional bacteria concentration and detection methods.

\begin{tabular}{|c|c|c|c|c|c|}
\hline Method & Type & Principle & Advantage & Limitation & Ref. \\
\hline Capillary Electrophoresis (CE) & Electro-dynamic & $\begin{array}{l}\text { Separation method based in sublimities } \\
\text { capillaries and micro/nano fluidic changes }\end{array}$ & $\begin{array}{l}\text { Technique that brings speed, } \\
\text { quantifiability, reproducibility } \\
\text { and automation }\end{array}$ & $\begin{array}{l}\text { Long separation times, poor specificity, sensitivity } \\
\text { of the analyte to the surrounding analytical } \\
\text { environment, requirements for sample purity, } \\
\text { and microbe aggregation. high salt buffers }\end{array}$ & [13] \\
\hline Mass Spectrometry (MS) & Chemical Method & $\begin{array}{l}\text { Identification of cells by breaking them into } \\
\text { ionized molecular fragments and measuring } \\
\text { mass/charge ratio of the products }\end{array}$ & $\begin{array}{l}\text { Fast technique with high sensitivity, } \\
\text { quantitative and qualitative analysis, } \\
\text { differentiates isotopes }\end{array}$ & $\begin{array}{l}\text { Lack of sample purity, chemical differences in cell } \\
\text { species, variations between stages of } \\
\text { cell development }\end{array}$ & [12] \\
\hline Centrifugation & Physical Method & $\begin{array}{l}\text { Separation technique based on the centrifugal } \\
\text { force that separate particles in solution } \\
\text { according to their size, shape, density, } \\
\text { and viscosity }\end{array}$ & $\begin{array}{l}\text { Rapid, inexpensive, simple, non-specific; } \\
\text { amenable to large sample sizes }\end{array}$ & $\begin{array}{l}\text { Bacteria adhere to and sediment with } \\
\text { matrix components }\end{array}$ & [6] \\
\hline Filtration & Physical Method & $\begin{array}{l}\text { Mechanic force used to separate solids from } \\
\text { fluids, liquids or gases by interposing } \\
\text { a medium through which only the fluid } \\
\text { can pass }\end{array}$ & $\begin{array}{l}\text { Rapid, inexpensive, simple, non-specific; } \\
\text { amenable to large sample sizes }\end{array}$ & $\begin{array}{l}\text { Limited to low particulate foods that will not clog } \\
\text { the filter and by the volume of sample that can be } \\
\text { passed through the filter (i.e., sample filterability). } \\
\text { Sample pre-treatment with enzymes and detergents } \\
\text { can increase sample filterability but may adversely } \\
\text { affect cell viability }\end{array}$ & [6] \\
\hline Immunoseparation & Biological Method & $\begin{array}{l}\text { Separation technique based the use of } \\
\text { immunoglobulins (antibodies) reactive with } \\
\text { the particles to be separated }\end{array}$ & $\begin{array}{l}\text { rapid, simple, standards } \\
\text { methods available }\end{array}$ & high-non-specific binding & [6] \\
\hline $\begin{array}{l}\text { Raman microprobe spectroscopy } \\
\text { (RMS) }\end{array}$ & Microscopy & $\begin{array}{l}\text { Spectroscopic fingerprint from the microbial } \\
\text { sample. Provides quantitative and qualitative } \\
\text { information that can be used to characterize, } \\
\text { discriminate and identify micro-organisms at } \\
\text { the single-cell level }\end{array}$ & $\begin{array}{l}\text { High sensitivity and unique } \\
\text { molecular specificity }\end{array}$ & $\begin{array}{l}\text { The signal in direct aqueous solution detection is } \\
\text { often weak because of the small polarizability of } \\
\text { most biological molecules compared with dye } \\
\text { probe molecules }\end{array}$ & {$[15,16]$} \\
\hline ELISA & Immunologic & $\begin{array}{l}\text { Use of antibodies to which enzymes have been } \\
\text { covalently bound. The antigen is rapped so } \\
\text { that it may be the target micro-organism or } \\
\text { target toxin }\end{array}$ & $\begin{array}{l}\text { Useful for detection of infectious and } \\
\text { toxigenic bacteria (ex. C. perfringens a } \\
\text { toxin in the intestinal contents of animals). } \\
\text { Able to differentiate the e and b toxins }\end{array}$ & $\begin{array}{l}\text { Is time-consuming, not very sensitive, and involves } \\
\text { laborious multiple steps }\end{array}$ & [162] \\
\hline Polymerase Chain Reaction (PCR) & $\begin{array}{l}\text { Nucleic acid } \\
\text { probe-based method }\end{array}$ & $\begin{array}{l}\text { Is an in vitro technique, which allows the } \\
\text { amplification of a specific DNA region that lies } \\
\text { between two regions of a known } \\
\text { DNA sequence }\end{array}$ & $\begin{array}{l}\text { Rapidly detects a wide range of } \\
\text { micro-organisms in foods, the } \\
\text { environment and in biological material. } \\
\text { Cheaper and robust technique }\end{array}$ & $\begin{array}{l}\text { A major disadvantage is that the amount of DNA } \\
\text { sequence known for a given organism } \\
\text { may be limited }\end{array}$ & [18] \\
\hline Ligase chain reaction (LCR) & $\begin{array}{l}\text { Nucleic acid } \\
\text { probe-based method }\end{array}$ & $\begin{array}{l}\text { An in vitro nucleic acid amplification } \\
\text { technique that exponentially amplifies targeted } \\
\text { DNA sequences }\end{array}$ & $\begin{array}{l}\text { Possesses unique advantages for sensitive } \\
\text { and specific miRNA detection. LCR } \\
\text { exhibits better specificity than primer } \\
\text { extension-based amplification, such as } \\
\text { PCR, RCA, LAMP }\end{array}$ & $\begin{array}{l}\text { Limited by gel electrophoresis separation or } \\
\text { heterogeneous analysis process, which brought } \\
\text { about multiplex steps, high cost, and long } \\
\text { analysis time }\end{array}$ & [17] \\
\hline Microarrays & Nucleic acid method & $\begin{array}{l}\text { Analysis of large numbers of genes at a high } \\
\text { resolution by the hybridization of labelled } \\
\text { DNA to a substrate containing thousands of } \\
\text { surface-immobilised DNA's or } \\
\text { oligonucleotides }\end{array}$ & $\begin{array}{l}\text { Micro-arrays allow thousands of specific } \\
\text { DNA or RNA sequences to be detected } \\
\text { simultaneously on a small glass or silica } \\
\text { slide only } 1-2 \mathrm{~cm}^{2} \text { in size }\end{array}$ & $\begin{array}{l}\text { Micro-array instruments are expensive, of limited } \\
\text { availability and require much skill in extracting } \\
\text { useful information from the plethora of available } \\
\text { data. However, this is an exciting area that appears } \\
\text { headed for a very bright future }\end{array}$ & [18] \\
\hline
\end{tabular}




\section{References}

1. Kirk, M.D.; Pires, S.M.; Black, R.E.; Caipo, M.; Crump, J.A.; Devleesschauwer, B.; Döpfer, D.; Fazil, A.; Fischer-Walker, C.L.; Hald, T.; et al. World Health Organization Estimates of the Global and Regional Disease Burden of 22 Foodborne Bacterial, Protozoal, and Viral Diseases, 2010: A Data Synthesis. PLOS Med. 2015, 12, e1001921. [CrossRef] [PubMed]

2. Prieto, M.; Colin, P.; Fernández-Escámez, P.; Alvarez-Ordóñez, A. Epidemiology, Detection, and Control of Foodborne Microbial Pathogens. Biomed Res. Int. 2015. [CrossRef] [PubMed]

3. Salter, S.J. The food-borne identity. Nat. Rev. Microbiol. 2014, 12, 533. [CrossRef] [PubMed]

4. Cabral, J.P.S. Water Microbiology. Bacterial Pathogens and Water. Int. J. Environ. Res. Public Health 2010, 7 , 3657-3703. [CrossRef] [PubMed]

5. Wang, Y.; Ye, Z.; Ying, Y. New trends in impedimetric biosensors for the detection of foodborne pathogenic bacteria. Sensors 2012, 12, 3449-3471. [CrossRef] [PubMed]

6. Stevens, K.A.; Jaykus, L.-A. Bacterial separation and concentration from complex sample matrices: A review. Crit. Rev. Microbiol. 2004, 30, 7-24. [CrossRef] [PubMed]

7. Lapizco-Encinas, B.H.; Davalos, R.V.; Simmons, B.A.; Cummings, E.B.; Fintschenko, Y. An insulator-based (electrodeless) dielectrophoretic concentrator for microbes in water. J. Microbiol. Methods 2005, 62, 317-326. [CrossRef] [PubMed]

8. Yager, P.; Edwards, T.; Fu, E.; Helton, K.; Nelson, K.; Tam, M.R.; Weigl, B.H. Microfluidic diagnostic technologies for global public health. Nature 2006, 442, 412-418. [CrossRef] [PubMed]

9. Urdea, M.; Penny, L.A.; Olmsted, S.S.; Giovanni, M.Y.; Kaspar, P.; Shepherd, A.; Wilson, P.; Dahl, C.A.; Buchsbaum, S.; Moeller, G.; et al. Requirements for high impact diagnostics in the developing world. Nature 2006, 444, 73-79. [CrossRef] [PubMed]

10. Lapizco-Encinas, B.H.; Simmons, B.A.; Cummings, E.B.; Fintschenko, Y. Dielectrophoretic concentration and separation of live and dead bacteria in an array of insulators. Anal. Chem. 2004, 76, 1571-1579. [CrossRef] [PubMed]

11. Li, Y.; Yan, X.; Feng, X.; Wang, J.; Du, W.; Wang, Y.; Chen, P.; Xiong, L.; Liu, B.-F. Agarose-Based Microfluidic Device for Point-of-Care Concentration and Detection of Pathogen. Anal. Chem. 2014, 86, 10653-10659. [CrossRef] [PubMed]

12. Jones, P.; DeMichele, A.; Kemp, L.; Hayes, M. Differentiation of Escherichia coli serotypes using DC gradient insulator dielectrophoresis. Anal. Bioanal. Chem. 2014, 406, 183-192. [CrossRef] [PubMed]

13. Petr, J.; Maier, V. Analysis of microorganisms by capillary electrophoresis. TrAC Trends Anal. Chem. 2012, 31, 9-22. [CrossRef]

14. Dastider, S.G.; Barizuddin, S.; Dweik, M.; Almasri, M. A micromachined impedance biosensor for accurate and rapid detection of E. coli O157:H7. RSC Adv. 2013, 3, 26297-26306. [CrossRef]

15. Yang, X.; Gu, C.; Qian, F.; Li, Y.; Zhang, J.Z. Highly sensitive detection of proteins and bacteria in aqueous solution using surface-enhanced Raman scattering and optical fibers. Anal. Chem. 2011, 83, 5888-5894. [CrossRef] [PubMed]

16. Marotta, N.E.; Beavers, K.R.; Bottomley, L.A. Limitations of surface enhanced Raman scattering in sensing DNA hybridization demonstrated by label-free DNA oligos as molecular rulers of distance-dependent enhancement. Anal. Chem. 2013, 85, 1440-1446. [CrossRef] [PubMed]

17. Yuan, Z.; Zhou, Y.; Gao, S.; Cheng, Y.; Li, Z. Homogeneous and sensitive detection of microRNA with ligase chain reaction and lambda exonuclease-assisted cationic conjugated polymer biosensing. ACS Appl. Mater. Interfaces 2014, 6, 6181-6185. [CrossRef] [PubMed]

18. Deisingh, A.K.; Thompson, M. Detection of infectious and toxigenic bacteria. Analyst 2002, 127, 567-581. [CrossRef] [PubMed]

19. Whitesides, G. The origins and the future of microfluidics. Nature 2006, 442, 368-373. [CrossRef] [PubMed]

20. Zordan, M.D.; Grafton, M.M.G.; Acharya, G.; Reece, L.M.; Cooper, C.L.; Aronson, A.I.; Park, K.; Leary, J.F. Detection of pathogenic E. coli O157:H7 by a hybrid microfluidic SPR and molecular imaging cytometry device. Cytometry. A 2009, 75, 155-162. [CrossRef] [PubMed]

21. Hamada, R.; Takayama, H. Improvement of dielectrophoretic impedance measurement method by bacterial concentration utilizing negative dielectrophoresis. J. PhysicsConference Ser. 2011, 307, 1-6. [CrossRef] 
22. Chin, C.D.; Linder, V.; Sia, S.K. Commercialization of microfluidic point-of-care diagnostic devices. Lab Chip 2012, 12, 2118-2134. [CrossRef] [PubMed]

23. Zhang, X.; Jiang, H.; Zhang, L.; Zhang, C.; Wang, Z.; Chen, X. An Energy-Efficient ASIC for Wireless Body Sensor Networks in Medical Applications. IEEE Trans. Biomed. Circuits Syst. 2010, 4, 11-18. [CrossRef] [PubMed]

24. Figeys, D.; Pinto, D. Lab-on-a-chip: A revolution in biological and medical sciences. Anal. Chem. 2000, 72, 330A-335A. [CrossRef] [PubMed]

25. Heo, J.; Hua, S.Z. An overview of recent strategies in pathogen sensing. Sensors 2009, 9, 4483-4502. [CrossRef] [PubMed]

26. Ríos, A.; Zougagh, M.; Avila, M. Miniaturization through lab-on-a-chip: Utopia or reality for routine laboratories? A review. Anal. Chim. Acta 2012, 740, 1-11. [CrossRef] [PubMed]

27. Mackenzie, A.; Orrbine, E.; Hyde, L.; Benoit, M.; Chan, F.; Park, C.; Alverson, J.; Lembke, A.; Hoban, D.; Kennedy, W. Performance of the ImmunoCard STAT! E. coli O157:H7 test for detection of Escherichia coli O157:H7 in stools. J. Clin. Microbiol. 2000, 38, 1866-1868. [PubMed]

28. Acheson, D.; McEntire, J.; Thorpe, C.M. Foodborne Illness: Latest Threats and Emerging Issues, an Issue of Infectious Disease Clinics; Elsevier Health Sciences: Philadelphia, PA, USA, 2013.

29. Cole, K. Permeability and impermeability of cell membranes for ions. Cold Spring Harb. Symp. Quant. Biol. 1940, 8, 110-122. [CrossRef]

30. Kim, M.; Jung, T.; Kim, Y.; Lee, C.; Woo, K.; Seol, J.H.; Yang, S. A microfluidic device for label-free detection of Escherichia coli in drinking water using positive dielectrophoretic focusing, capturing, and impedance measurement. Biosens. Bioelectron. 2015, 74, 1011-1015. [CrossRef] [PubMed]

31. Del Moral Zamora, B.; Álvarez Azpeitia, J.M.; Oliva Brañas, A.M.; Colomer-Farrarons, J.; Castellarnau, M.; Miribel-Català, P.L.; Homs-Corbera, A.; Juárez, A.; Samitier, J. Dielectrophoretic concentrator enhancement based on dielectric poles for continuously flowing samples. Electrophoresis 2015, 36, 1405-1413. [CrossRef] [PubMed]

32. Pohl, H.A.; Hawk, I. Separation of living and dead cells by dielectrophoresis. Science 1966, 152, 647-649. [CrossRef] [PubMed]

33. Pethig, R.; Markx, G.H. Applications of dielectrophoresis in biotechnology. Trends Biotechnol. 1997, 15, 426-432. [CrossRef]

34. Lapizco-Encinas, B.H. Editorial: Dielectrophoresis 2015. Electrophoresis 2015, 36, 1385. [CrossRef] [PubMed]

35. Hamada, R.; Takayama, H.; Shonishi, Y.; Mao, L.; Nakano, M.; Suehiro, J. A rapid bacteria detection technique utilizing impedance measurement combined with positive and negative dielectrophoresis. Sens. Actuators B Chem. 2013, 181, 439-445. [CrossRef]

36. Del Moral-Zamora, B.; Punter-Villagrassa, J.; Oliva-Brañas, A.M.; Álvarez-Azpeitia, J.M.; Colomer-Farrarons, J.; Samitier, J.; Homs-Corbera, A.; Miribel-Català, P.L. Combined dielectrophoretic and impedance system for on-chip controlled bacteria concentration: Application to Escherichia coli. Electrophoresis 2015, 36, 1130-1141. [CrossRef] [PubMed]

37. Couniot, N.; Francis, L.A.; Flandre, D. Resonant dielectrophoresis and electrohydrodynamics for high-sensitivity impedance detection of whole-cell bacteria. Lab Chip 2015, 15, 3183-3191. [CrossRef] [PubMed]

38. Suehiro, J.; Hamada, R.; Noutomi, D.; Shutou, M.; Hara, M. Selective detection of viable bacteria using dielectrophoretic impedance measurement method. J. Electrostat. 2003, 57, 157-168. [CrossRef]

39. Chen, L.; Zheng, X.-L.; Hu, N.; Yang, J.; Luo, H.-Y.; Jiang, F.; Liao, Y.-J. Research Progress on Microfluidic Chip of Cell Separation Based on Dielectrophoresis. Chinese J. Anal. Chem. 2015, 43, 300-309. [CrossRef]

40. Dwivedi, H.P.; Jaykus, L.-A. Detection of pathogens in foods: The current state-of-the-art and future directions. Crit. Rev. Microbiol. 2011, 37, 40-63. [CrossRef] [PubMed]

41. Demircan, Y.; Özgür, E.; Külah, H. Dielectrophoresis: Applications and future outlook in point of care. Electrophoresis 2013, 34, 1008-1027. [CrossRef] [PubMed]

42. Ikeda, I.; Monjushiro, H.; Watarai, H. Measurement of dielectrophoretic mobility of single micro-particles in a flow channel. Analyst 2005, 130, 1340-1342. [CrossRef] [PubMed]

43. Crane, J.; Pohl, H. A study of living and dead yeast cells using dielectrophoresis. J. Electrochem. Soc. 1968, 115, 584-586. [CrossRef] 
44. Allsopp, D.W.E.; Milner, K.R.; Brown, A.P.; Betts, W.B. Impedance technique for measuring dielectrophoretic collection of microbiological particles. J. Phys. D Appl. Phys. 1999, 32, 1066-1074. [CrossRef]

45. Medoro, G.; Manaresi, N. A lab-on-a-chip for cell detection and manipulation. Sens. J. 2003, 3, 317-325. [CrossRef]

46. Sabounchi, P.; Morales, A.M.; Ponce, P.; Lee, L.P.; Simmons, B.A.; Davalos, R.V. Sample concentration and impedance detection on a microfluidic polymer chip. Biomed. Microdevices 2008, 10, 661-670. [CrossRef] [PubMed]

47. Jones, T.B. Electromechanics of Particles; Cambridge University Press: New York, NY, USA, 2005.

48. Van den Driesche, S.; Rao, V.; Puchberger-Enengl, D.; Witarski, W.; Vellekoop, M.J. Continuous cell from cell separation by traveling wave dielectrophoresis. Sens. Actuators B Chem. 2012, 170, 207-214. [CrossRef]

49. Ino, K.; Ishida, A.; Inoue, K.Y.; Suzuki, M.; Koide, M.; Yasukawa, T.; Shiku, H.; Matsue, T. Electrorotation chip consisting of three-dimensional interdigitated array electrodes. Sens. Actuators B Chem. 2011, 153, 468-473. [CrossRef]

50. Issadore, D.; Franke, T.; Brown, K.A.; Westervelt, R.M. A microfluidic microprocessor: Controlling biomimetic containers and cells using hybrid integrated circuit/microfluidic chips. Lab Chip 2010, 10, 2937-2943. [CrossRef] [PubMed]

51. Cheng, I.-F.; Chung, C.-C.; Chang, H.-C. High-throughput electrokinetic bioparticle focusing based on a travelling-wave dielectrophoretic field. Microfluid. Nanofluid. 2010, 10, 649-660. [CrossRef]

52. Miled, M.; Sawan, M. Dielectrophoresis-based integrated lab-on-chip for nano and micro-particles manipulation and capacitive detection. IEEE Trans. Biomed. Circuits Syst. 2012, 6, 120-132. [CrossRef] [PubMed]

53. Zhang, J.Y.; Do, J.; Premasiri, W.R.; Ziegler, L.D.; Klapperich, C.M. Rapid point-of-care concentration of bacteria in a disposable microfluidic device using meniscus dragging effect. Lab Chip 2010, 10, 3265-3270. [CrossRef] [PubMed]

54. Yoo, J.; Cha, M.; Lee, J. Bacterial concentration detection with dielectrophoresis and capacitive measurement. In Proceedings of the NSTI Nanotechnology Conference and Trade Show, Boston, MA, USA, 1-5 June 2008; pp. 611-614.

55. Yang, L.; Bashir, R. Electrical/electrochemical impedance for rapid detection of foodborne pathogenic bacteria. Biotechnol. Adv. 2008, 26, 135-150. [CrossRef] [PubMed]

56. Everwand, M.; Anselmetti, D.; Regtmeier, J. On-Chip Continuous Flow Interaction Studies of DNA and Protein Complexed DNA. In Proceedings of the 14th International Conference on Miniaturized Systems for Chemistry and Life Sciences, Groningen, The Netherlands, 3-7 October 2010; pp. 19-21.

57. Xu, C.; Wang, Y.; Cao, M.; Lu, Z. Dielectrophoresis of human red cells in microchips. Electrophoresis 1999, 20, 1829-1831. [CrossRef]

58. Borgatti, M.; Bianchi, N.; Mancini, I.; Feriotto, G.; Gambari, R. New trends in non-invasive prenatal diagnosis: Applications of dielectrophoresis-based Lab-on-a-chip platforms to the identification and manipulation of rare cells. Int. J. Mol. Med. 2008, 21, 3-12. [CrossRef] [PubMed]

59. Mernier, G.; Duqi, E.; Renaud, P. Characterization of a novel impedance cytometer design and its integration with lateral focusing by dielectrophoresis. Lab Chip 2012, 12, 4344-4349. [CrossRef] [PubMed]

60. Zhu, J.; Canter, R.C.; Keten, G.; Vedantam, P.; Tzeng, T.-R.J.; Xuan, X. Continuous-flow particle and cell separations in a serpentine microchannel via curvature-induced dielectrophoresis. Microfluid. Nanofluidics 2011, 11, 743-752. [CrossRef]

61. Patel, P.M.; Bhat, A.; Markx, G.H. A comparative study of cell death using electrical capacitance measurements and dielectrophoresis. Enzym. Microb. Technol. 2008, 43, 523-530. [CrossRef]

62. Valero, A.; Braschler, T.; Rauch, A.; Demierre, N.; Barral, Y.; Renaud, P. Tracking and synchronization of the yeast cell cycle using dielectrophoretic opacity. Lab Chip 2011, 11, 1754-1760. [CrossRef] [PubMed]

63. Cummings, E.B.; Singh, A.K. Dielectrophoresis in microchips containing arrays of insulating posts: Theoretical and experimental results. Anal. Chem. 2003, 75, 4724-4731. [CrossRef] [PubMed]

64. Gallo-Villanueva, R.C.; Rodríguez-López, C.E.; Díaz-de-la-Garza, R.I.; Reyes-Betanzo, C.; Lapizco-Encinas, B.H. DNA manipulation by means of insulator-based dielectrophoresis employing direct current electric fields. Electrophoresis 2009, 30, 4195-4205. [CrossRef] [PubMed] 
65. Gupta, V.; Jafferji, I.; Garza, M.; Melnikova, V.O.; Hasegawa, D.K.; Pethig, R.; Davis, D.W. ApoStream ${ }^{\mathrm{TM}}$, a new dielectrophoretic device for antibody independent isolation and recovery of viable cancer cells from blood. Biomicrofluidics 2012, 6, 024133. [CrossRef] [PubMed]

66. Wei, C.; Wei, T.-Y.; Liang, C.-H.; Tai, F.-C. The separation of different conducting multi-walled carbon nanotubes by AC dielectrophoresis. Diam. Relat. Mater. 2009, 18, 332-336. [CrossRef]

67. Morgan, H.; Hughes, M.P.; Green, N.G. Separation of submicron bioparticles by dielectrophoresis. Biophys. J. 1999, 77, 516-525. [CrossRef]

68. Gascoyne, P.R.C.; Vykoukal, J. Particle separation by dielectrophoresis. Electrophoresis 2002, 23, $1973-1983$. [CrossRef]

69. Gascoyne, P.R.C.; Vykoukal, J.V. Dielectrophoresis-Based Sample Handling in General-Purpose Programmable Diagnostic Instruments. Proc. IEEE. Inst. Electr. Electron. Eng. 2004, 92, 22-42. [CrossRef] [PubMed]

70. Lui, C.; Cady, N.C.; Batt, C.A. Nucleic Acid-Based Detection of Bacterial Pathogens Using Integrated Microfluidic Platform Systems. Sensors 2009, 9, 3713-3144. [CrossRef] [PubMed]

71. Zou, Z.; Lee, S.; Ahn, C.H. A Polymer Microfluidic Chip with Interdigitated Electrodes Arrays for Simultaneous Dielectrophoretic Manipulation and Impedimetric Detection of Microparticles. IEEE Sens. J. 2008, 8, 527-535. [CrossRef]

72. Zou, Z.; Kai, J.; Rust, M.J.; Han, J.; Ahn, C.H. Functionalized nano interdigitated electrodes arrays on polymer with integrated microfluidics for direct bio-affinity sensing using impedimetric measurement. Sens. Actuators A Phys. 2007, 136, 518-526. [CrossRef]

73. Gawad, S.; Schild, L.; Renaud, P.H. Micromachined impedance spectroscopy flow cytometer for cell analysis and particle sizing. Lab Chip 2001, 1, 76-82. [CrossRef] [PubMed]

74. Gozzini, F.; Ferrari, G.; Sampietro, M. An instrument-on-chip for impedance measurements on nanobiosensors with attoFarad resoution. In Proceedings of the 2009 IEEE International Solid-State Circuits Conference, San Francisco, CA, USA, 8-12 February 2009; IEEE: San Francisco, CA, USA, 2009; pp. $346-347$.

75. Giaever, I.; Keese, C.R. A morphological biosensor for mammalian cells. Nature 1993, 366, 591-592. [CrossRef] [PubMed]

76. Yang, M.; Lim, C.C.; Liao, R.; Zhang, X. A novel microfluidic impedance assay for monitoring endothelin-induced cardiomyocyte hypertrophy. Biosens. Bioelectron. 2007, 22, 1688-1693. [CrossRef] [PubMed]

77. Varshney, M.; Li, Y. Interdigitated array microelectrodes based impedance biosensors for detection of bacterial cells. Biosens. Bioelectron. 2009, 24, 2951-2960. [CrossRef] [PubMed]

78. Du, E.; Ha, S.; Diez-Silva, M.; Dao, M.; Suresh, S.; Chandrakasan, A.P. Electric impedance microflow cytometry for characterization of cell disease states. Lab Chip 2013, 13, 3903-3909. [CrossRef] [PubMed]

79. Foudeh, A.M.; Fatanat Didar, T.; Veres, T.; Tabrizian, M. Microfluidic designs and techniques using lab-on-a-chip devices for pathogen detection for point-of-care diagnostics. Lab Chip 2012, 12, 3249-3266. [CrossRef] [PubMed]

80. Rodriguez, M.C.; Kawde, A.-N.; Wang, J. Aptamer biosensor for label-free impedance spectroscopy detection of proteins based on recognition-induced switching of the surface charge. Chem. Commun. 2005, 4267-4269. [CrossRef] [PubMed]

81. Tiruppathi, C.; Malik, A.B.; Del Vecchio, P.J.; Keese, C.R.; Giaever, I. Electrical method for detection of endothelial cell shape change in real time: assessment of endothelial barrier function. Proc. Natl. Acad. Sci. USA 1992, 89, 7919-7923. [CrossRef] [PubMed]

82. Ramaswamy, B.; Yeh, Y.-T.T.; Zheng, S.-Y. Microfluidic device and system for point-of-care blood coagulation measurement based on electrical impedance sensing. Sens. Actuators B Chem. 2013, 180, 21-27. [CrossRef]

83. Sun, T.; Morgan, H. Single-cell microfluidic impedance cytometry: A review. Microfluid. Nanofluidics 2010, 8, 423-443. [CrossRef]

84. Xu, M.; Luo, X.; Davis, J.J. The label free picomolar detection of insulin in blood serum. Biosens. Bioelectron. 2013, 39, 21-25. [CrossRef] [PubMed]

85. Huang, Y.; Bell, M.C.; Suni, I.I. Impedance biosensor for peanut protein Ara h 1. Anal. Chem. 2008, 80, 9157-9161. [CrossRef] [PubMed]

86. Ramírez, N.; Regueiro, A.; Arias, O.; Contreras, R. Espectroscopía de impedancia electroquímica, herramienta eficaz para el diagnóstico rápido microbiológico. Biotecnol. Apl. 2009, 26, 72-78. 
87. Stewart, G.N. The charges produced by the growth of bacteria in the molecular concentration and electrical condustivity of culture media. J. Exp. Med. 1899, 4, 235-243. [CrossRef] [PubMed]

88. Grossi, M.; Lanzoni, M.; Pompei, A.; Lazzarini, R.; Matteuzzi, D.; Riccò, B. An embedded portable biosensor system for bacterial concentration detection. Biosens. Bioelectron. 2010, 26, 983-990. [CrossRef] [PubMed]

89. Yang, L. Electrical impedance spectroscopy for detection of bacterial cells in suspensions using interdigitated microelectrodes. Talanta 2008, 74, 1621-1629. [CrossRef] [PubMed]

90. Suehiro, J.; Noutomi, D.; Hamada, R.; Hara, M. Selective detection of specific bacteria using dielectrophoretic impedance measurement method combined with an antigen-antibody reaction. J. Electrostat. 2003, 58, 229-246. [CrossRef]

91. Easter, M.C.; Gibson, D.M. Rapid and automated detection of salmonella by electrical measurements. J. Hyg. 1985, 94, 245-262. [CrossRef] [PubMed]

92. Smith, P.J.; Bolton, F.J.; Gayner, V.E.; Eccles, A. Improvements to a lysine medium for detection of salmonellas by electrical conductance. Lett. Appl. Microbiol. 2008, 11, 84-86. [CrossRef]

93. Blivet, D.; Salvat, G.; Humbert, F.; Colin, P. Development of a new culture medium for the rapid detection of Salmonella by indirect conductance measurements. J. Appl. Microbiol. 1998, 84, 399-403. [CrossRef] [PubMed]

94. Varshney, M.; Li, Y. Interdigitated array microelectrode based impedance biosensor coupled with magnetic nanoparticle-antibody conjugates for detection of Escherichia coli O157:H7 in food samples. Biosens. Bioelectron. 2007, 22, 2408-2414. [CrossRef] [PubMed]

95. Timms, S.; Colquhoun, K.O.; Fricker, C.R. Detection of Escherichia coli in potable water using indirect impedance technology. J. Microbiol. Methods 1996, 26, 125-132. [CrossRef]

96. Gomez-Sjoberg, R.; Morisette, D.T.; Bashir, R. Impedance microbiology-on-a-chip: Microfluidic bioprocessor for rapid detection of bacterial metabolism. J. Microelectromechan. Syst. 2005, 14, 829-838. [CrossRef]

97. Glassmoyer, K.E.; Russell, S.M. Evaluation of a selective broth for detection of Staphylococcus aureus using impedance microbiology. J. Food Prot. 2001, 64, 44-50. [PubMed]

98. Spiller, E.; Schöll, A.; Alexy, R.; Kümmerer, K.; Urban, G.A. A microsystem for growth inhibition test of Enterococcus faecalis based on impedance measurement. Sens. Actuators B Chem. 2006, 118, 182-191. [CrossRef]

99. Richards, J.; Jason, A.; Hobbs, G.; Gibson, D.; Christie, R. Electronic measurement of bacterial growth. J. Phys. E 1978, 11, 560-568. [CrossRef] [PubMed]

100. Nakano, M.; Ding, Z.; Kasahara, H.; Suehiro, J. Rapid microbead-based DNA detection using dielectrophoresis and impedance measurement. EPL 2014, 108, 28003. [CrossRef]

101. Henning, A.; Bier, F.F.; Hölzel, R. Dielectrophoresis of DNA: Quantification by impedance measurements. Biomicrofluidics 2010, 4, 022803. [CrossRef] [PubMed]

102. Krishnan, R.; Sullivan, B.D.; Mifflin, R.L.; Esener, S.C.; Heller, M.J. Alternating current electrokinetic separation and detection of DNA nanoparticles in high-conductance solutions. Electrophoresis 2008, 29, 1765-1774. [CrossRef] [PubMed]

103. Suehiro, J.; Shutou, M.; Hatano, T.; Hara, M. High sensitive detection of biological cells using dielectrophoretic impedance measurement method combined with electropermeabilization. Sens. Actuators B Chem. 2003, 96, 144-151. [CrossRef]

104. Nakano, M.; Ding, Z.; Suehiro, J. Dielectrophoresis and dielectrophoretic impedance detection of adenovirus and rotavirus. Jpn. J. Appl. Phys. 2016, 55, 017001. [CrossRef]

105. Mohanty, S.K.; Ravula, S.K.; Engisch, K.L.; Frazier, A.B. A micro system using dielectrophoresis and electrical impedance spectroscopy for cell manipulation and analysis. In Proceedings of the 12th International Conference on TRANSDUCERS, Solid-State Sensors, Actuators and Microsystems, Boston, MA, USA, 8-12 June 2003; Volume 2, pp. 1055-1058.

106. Ameri, S.K.; Singh, P.K.; Dokmeci, M.R.; Khademhosseini, A.; Xu, Q.; Sonkusale, S.R. All electronic approach for high-throughput cell trapping and lysis with electrical impedance monitoring. Biosens. Bioelectron. 2014, 54, 462-467. [CrossRef] [PubMed]

107. Park, H.; Kim, D.; Yun, K.-S. Single-cell manipulation on microfluidic chip by dielectrophoretic actuation and impedance detection. Sens. Actuators B Chem. 2010, 150, 167-173. [CrossRef]

108. Lan, K.-C.; Jang, L.-S. Integration of single-cell trapping and impedance measurement utilizing microwell electrodes. Biosens. Bioelectron. 2011, 26, 2025-2031. [CrossRef] [PubMed] 
109. Lennon, E.; Ostrovidov, S.; Senez, V.; Fujii, T. Dielectrophoresis, cell culture, and Electrical Impedance Spectroscopy Applied to Adherent Cells in a Single Biochip. In Proceedings of the 2006 International Conference on Microtechnologies in Medicine and Biology, Okinawa, Japan, 9-12 May 2006; pp. 165-168.

110. Chuang, C.-H.; Huang, Y.-W.; Wu, Y.-T. System-level biochip for impedance sensing and programmable manipulation of bladder cancer cells. Sensors 2011, 11, 11021-11035. [CrossRef] [PubMed]

111. Hirota, K.; Inagaki, S.; Hamada, R.; Ishihara, K.; Miyake, Y. Evaluation of a Rapid Oral Bacteria Quantification System Using Dielectrophoresis and the Impedance Measurement. Biocontrol Sci. 2014, 19, 45-49. [CrossRef] [PubMed]

112. Ishii, Y.; Imamura, K.; Kikuchi, Y.; Miyagawa, S.; Hamada, R.; Sekino, J.; Sugito, H.; Ishihara, K.; Saito, A. Point-of-care detection of Tannerella forsythia using an antigen-antibody assisted dielectrophoretic impedance measurement method. Microb. Pathog. 2015, 82, 37-42. [CrossRef] [PubMed]

113. Takahashi, S.; Kuratani, M.; Tanaka, M.; Ito, T.; Kanemaki, N.; Shirai, M.; Nomura, R.; Nakano, K.; Asai, F. Measurement of oral bacterial counts in dogs by dielectrophoretic impedance. Fundam. Toxicol. Sci. 2015, 2, 83-87. [CrossRef]

114. Radke, S.M.; Alocilja, E.C. A high density microelectrode array biosensor for detection of E. coli O157:H7. Biosens. Bioelectron. 2005, 20, 1662-1667. [CrossRef] [PubMed]

115. Brown, A.P.; Betts, W.B.; Harrison, A.B.; O’Neill, J.G. Evaluation of a dielectrophoretic bacterial counting technique. Biosens. Bioelectron. 1999, 14, 341-351. [CrossRef]

116. Suehiro, J.; Hatano, T.; Shutou, M.; Hara, M. Improvement of electric pulse shape for electropermeabilization-assisted dielectrophoretic impedance measurement for high sensitive bacteria detection. Sens. Actuators B Chem. 2005, 109, 209-215. [CrossRef]

117. Müller, T.; Gradl, G.; Howitz, S.; Shirley, S.; Schnelle, T.; Fuhr, G. A 3-D microelectrode system for handling and caging single cells and particles. Biosens. Bioelectron. 1999, 14, 247-256. [CrossRef]

118. Fry, C.H.; Salvage, S.C.; Manazza, A.; Dupont, E.; Labeed, F.H.; Hughes, M.P.; Jabr, R.I. Cytoplasm resistivity of mammalian atrial myocardium determined by dielectrophoresis and impedance methods. Biophys. J. 2012, 103, 2287-2294. [CrossRef] [PubMed]

119. Suehiro, J.; Yatsunami, R.; Hamada, R.; Hara, M. Quantitative estimation of biological cell concentration suspended in aqueous medium by using dielectrophoretic impedance measurement method. J. Phys. D. Appl. Phys. 1999, 32, 2814-2820. [CrossRef]

120. Shafiee, H.; Caldwell, J.L.; Sano, M.B.; Davalos, R.V. Contactless dielectrophoresis: a new technique for cell manipulation. Biomed. Microdevices 2009, 11, 997-1006. [CrossRef] [PubMed]

121. Sano, M.B.; Caldwell, J.L.; Davalos, R.V. Modeling and development of a low frequency contactless dielectrophoresis (cDEP) platform to sort cancer cells from dilute whole blood samples. Biosens. Bioelectron. 2011, 30, 13-20. [CrossRef] [PubMed]

122. Suehiro, J.; Ohtsubo, A.; Hatano, T.; Hara, M. Selective detection of bacteria by a dielectrophoretic impedance measurement method using an antibody-immobilized electrode chip. Sens. Actuators B Chem. 2006, 119, 319-326. [CrossRef]

123. Boehm, D.A.; Gottlieb, P.A.; Hua, S.Z. On-chip microfluidic biosensor for bacterial detection and identification. Sens. Actuators B Chem. 2007, 126, 508-514. [CrossRef]

124. Dweik, M.; Stringer, R.C.; Dastider, S.G.; Wu, Y.; Almasri, M.; Barizuddin, S. Specific and targeted detection of viable Escherichia coli O157:H7 using a sensitive and reusable impedance biosensor with dose and time response studies. Talanta 2012, 94, 84-89. [CrossRef] [PubMed]

125. Beck, J.D.; Shang, L.; Li, B.; Marcus, M.S.; Hamers, R.J. Discrimination between Bacillus species by impedance analysis of individual dielectrophoretically positioned spores. Anal. Chem. 2008, 80, 3757-3761. [CrossRef] [PubMed]

126. Maas, S.L.N.; de Vrij, J.; van der Vlist, E.J.; Geragousian, B.; van Bloois, L.; Mastrobattista, E.; Schiffelers, R.M.; Wauben, M.H.M.; Broekman, M.L.D.; Nolte-'t Hoen, E.N.M. Possibilities and limitations of current technologies for quantification of biological extracellular vesicles and synthetic mimics. J. Control. Release 2015, 200, 87-96. [CrossRef] [PubMed]

127. Filipe, V.; Poole, R.; Kutscher, M.; Forier, K.; Braeckmans, K.; Jiskoot, W. Fluorescence single particle tracking for the characterization of submicron protein aggregates in biological fluids and complex formulations. Pharm. Res. 2011, 28, 1112-1120. [CrossRef] [PubMed] 
128. Gwon, H.R.; Chang, S.T.; Choi, C.K.; Jung, J.-Y.; Kim, J.-M.; Lee, S.H. Development of a new contactless dielectrophoresis system for active particle manipulation using movable liquid electrodes. Electrophoresis 2014, 35, 2014-2021. [CrossRef] [PubMed]

129. Demierre, N.; Braschler, T.; Muller, R.; Renaud, P. Focusing and continuous separation of cells in a microfluidic device using lateral dielectrophoresis. Sens. Actuators B Chem. 2008, 132, 388-396. [CrossRef]

130. Demierre, N.; Braschler, T.; Linderholm, P.; Seger, U.; van Lintel, H.; Renaud, P. Characterization and optimization of liquid electrodes for lateral dielectrophoresis. Lab Chip 2007, 7, 355-365. [CrossRef] [PubMed]

131. Hughes, M.P. Strategies for dielectrophoretic separation in laboratory-on-a-chip systems. Electrophoresis 2002 , 23, 2569-2582. [CrossRef]

132. Martinez-Duarte, R. Microfabrication technologies in dielectrophoresis applications-A review. Electrophoresis 2012, 33, 3110-3132. [CrossRef] [PubMed]

133. Shaker, M.; Colella, L.; Caselli, F.; Bisegna, P.; Renaud, P. An impedance-based flow microcytometer for single cell morphology discrimination. Lab Chip 2014, 14, 2548-2555. [CrossRef] [PubMed]

134. Li, M.; Li, S.; Cao, W.; Li, W.; Wen, W.; Alici, G. Improved concentration and separation of particles in a 3D dielectrophoretic chip integrating focusing, aligning and trapping. Microfluid. Nanofluid. 2012, 14, 527-539. [CrossRef]

135. Volpatti, L.R.; Yetisen, A.K. Commercialization of microfluidic devices. Trends Biotechnol. 2014, 32, 347-350. [CrossRef] [PubMed]

136. Regtmeier, J.; Eichhorn, R.; Viefhues, M.; Bogunovic, L.; Anselmetti, D. Electrodeless dielectrophoresis for bioanalysis: Theory, devices and applications. Electrophoresis 2011, 32, 2253-2273. [CrossRef] [PubMed]

137. Kadri, N.A.; Fatoyinbo, H.O.; Hughes, M.P.; Labeed, F.H. Semi-automated Dielectrophoretic Cell Characterisation Module for Lab-on-Chip Applications. IFMBE Proc. 2011, 35, 582-586.

138. Del Moral Zamora, B.; Alvarez Azpeitia, J.M.; Colomer-Farrarons, J.; Miribel-Catala, P.Ll.; Homs-Corbera, A.; Juarez, A.; Samitier, J. Towards Point-of-Use Dielectrophoretic Methods: A new Portable Multiphase Generator for Bacteria Concentration. IFMBE Proc. 2013, 41, 856-859.

139. Mohammed, M.I.; Haswell, S.; Gibson, I. Lab-on-a-chip or Chip-in-a-lab: Challenges of Commercialization Lost in Translation. Proc. Technol. 2015, 20, 54-59. [CrossRef]

140. Hogan, J. Lab on a chip: A little goes a long way. Nature 2006, 442, 351-352. [CrossRef] [PubMed]

141. Islam, N.; Miyazaki, K. An empirical analysis of nanotechnology research domains. Technovation 2010, 30, 229-237. [CrossRef]

142. Punter-Villagrasa, J.; Cid, J.; Páez-Avilés, C.; Rodríguez-Villarreal, I.; Juanola-Feliu, E.; Colomer-Farrarons, J.; Miribel-Català, P. An Instantaneous Low-Cost Point-of-Care Anemia Detection Device. Sensors 2015, 15, 4564-4577. [CrossRef] [PubMed]

143. Butter, M.; Fischer, N.; Gjsberts, G.; Hartmann, C.; de Heide, M.; van der Zee, F. Horizon 2020: Key Enabling Technologies (KETs), Booster for European Leadership in the Manufacturing Sector; Study for the ITRE Committee: Brussels, Belgium, 2014.

144. Páez-Avilés, C.; Juanola-Feliu, E.; Bogachan-Tahirbegi, I.; Mir, M.; Gonzales-Piñero, M.; Samitier, J. Innovation and Technology Transfer of Medical Devices Fostered by Cross-disciplinary Commmunities of Practitioners. Int. J. Innov. Manag. 2015, 19, 1-27. [CrossRef]

145. European Commision A European Strategy for Key Enabling Technologies-A Bridge to Growth and Jobs. A Comunication from the Commission to the European Parliament, the Council, the European Economic and Social Committee and the Committee of the Regions. 2012. Available online: http:/ /eur-lex.europa.eu/ LexUriServ/LexUriServ.do?uri=COM:2012:0341:FIN:EN:PDF (accessed on 14 September 2016).

146. Kawabata, T.; Washizu, M. Dielectrophoretic detection of molecular bindings. IEEE Trans. Ind. Appl. 2001, 37, 1625-1633. [CrossRef]

147. Gomez, F. The future of microfluidic point-of-care diagnostic devices. Bioanalysis 2013, 5, 1-3. [CrossRef] [PubMed]

148. Yang, C.; Tsai, C.; Cheng, K.; Chen, S. Low-Invasive Implantable Devices of Low-Power Consumption Using High-Efficiency Antennas for Cloud Health Care. IEEE J. Emerg. Sel. Top. Circuits Syst. 2012, 2, 14-23. [CrossRef]

149. Jani, I.V.; Peter, T.F. How Point-of-Care Testing Could Drive Innovation in Global Health. N. Engl. J. Med. 2013, 368, 2319-2324. [CrossRef] [PubMed] 
150. Altomare, L.; Borgatti, M.; Medoro, G.; Manaresi, N.; Tartagni, M.; Guerrieri, R.; Gambari, R. Levitation and movement of human tumor cells using a printed circuit board device based on software-controlled dielectrophoresis. Biotechnol. Bioeng. 2003, 82, 474-479. [CrossRef] [PubMed]

151. Andersen, P.D.; Jørgensen, B.H.; Lading, L.; Rasmussen, B. Sensor foresight-Technology and market. Technovation 2004, 24, 311-320. [CrossRef]

152. Abel, G. Current status and future prospects of point-of-care testing around the globe. Expert Rev. Mol. Diagn. 2015, 15, 853-855. [CrossRef] [PubMed]

153. Fu, B.E.; Yager, P.; Floriano, P.N.; Christodoulides, N.; Mcdevitt, J.T. Perspective on Diagnostics for Global Health. IEEE Pulse 2011, 2, 40-50. [CrossRef] [PubMed]

154. Neužil, P.; Campos, C.D.M.; Wong, C.C.; Soon, J.B.W.; Reboud, J.; Manz, A. From chip-in-a-lab to lab-on-a-chip: Towards a single handheld electronic system for multiple application-specific lab-on-a-chip (ASLOC). Lab Chip 2014, 14, 2168-2176. [CrossRef] [PubMed]

155. Maine, E.; Lubik, S.; Garnsey, E. Value creation strategies for science-based business: A study of advanced materials ventures. Innov. Manag. Policy Pract. 2013, 15, 35-51. [CrossRef]

156. $\mathrm{Hu}, \mathrm{Y}$. Hyperlinked actors in the global knowledge communities and diffusion of innovation tools in nascent industrial field. Technovation 2013, 33, 38-49. [CrossRef]

157. Van Looy, B.; Ranga, M.; Callaert, J.; Debackere, K.; Zimmermann, E. Combining entrepreneurial and scientific performance in academia: Towards a compounded and reciprocal Matthew-effect? Res. Policy 2004, 33, 425-441. [CrossRef]

158. Kalisz, D.; Aluchna, M. Research and Innovation redefined. Perspectives on the European Union initiatives on Horizon 2020. Eur. Integr. Stud. 2012, 6, 140-149.

159. Dogramatzis, D. Healthcare Biotechnology: A Practical Guide; CRC Press: Boca Raton, FL, USA, 2010.

160. Juanola-Feliu, E.; Colomer-Farrarons, J.; Miribel-Català, P.; Samitier, J.; Valls-Pasola, J. Market challenges facing academic research in commercializing nano-enabled implantable devices for in-vivo biomedical analysis. Technovation 2012, 32, 193-204. [CrossRef]

161. Leydesdorff, L. The Triple Helix, Quadruple Helix, . . , and an N-Tuple of Helices: Explanatory Models for Analyzing the Knowledge-Based Economy? J. Knowl. Econ. 2011, 3, 25-35. [CrossRef]

162. Cho, I.-H.; Irudayaraj, J. In-situ immuno-gold nanoparticle network ELISA biosensors for pathogen detection. Int. J. Food Microbiol. 2013, 164, 70-75. [CrossRef] [PubMed] 